\title{
STRICT CONSTRUCTION OF FIREARMS OFFENSES: THE SUPREME COURT AND THE GUN CONTROL ACT OF 1968
}

\author{
RoBERT BATEY* \\ I \\ INTRODUCTION
}

Direct limits on the exercise of discretion in law enforcement are commonplace in modern criminal law. The fourth and fifth amendments to the United States Constitution restrict police investigations of suspected criminal activity, while the due process and equal protection clauses regulate the discretion of prosecutors to file criminal charges. Less obvious as limits on police and prosecutorial discretion are the rules governing the statutory definition of crime. By requiring prospective enunciation, in clear terms, of what conduct is criminal and by interpreting any residual ambiguity in statutory terms in favor of the defendant, courts significantly narrow police and prosecutorial law enforcement authority.

This article seeks to demonstrate the utility of the latter principle, the rule of strict construction of criminal statutes, as a limit on overzealous law enforcement. The article focuses on United States Supreme Court cases interpreting the Gun Control Act of 1968 (the 1968 Act). ${ }^{1}$ These decisions provide a unique demonstration of the relation between direct and indirect controls on enforcement. In its first three cases under the $1968 \mathrm{Act}^{2}{ }^{2}$ the Court faced fourth ${ }^{3}$ and fifth amendment issues, ${ }^{4}$ as well as construction

Copyright (C) 1986 by Law and Contemporary Problems

* Associate Dean and Professor, Stetson University College of Law.

Four graduates of Stetson University College of Law-Robert Butterfield, Kevin Fantauzzo, David Heil, and Matthew King-aided in the preparation of this article. At the editorial conference for the symposium, a discussion group including David Caplan, Susan Wimmershoff-Caplan, Penny Crook, Margaret Howard, James Jacobs, Don Kates, Gary Kleck, Daniel Polsby, and Robert Shalhope made helpful suggestions. Don Kates' editorial assistance was invaluable: without his insight and vast knowledge of the area, I would not have been able to write this article. Of course, none of these persons bears any responsibility for the work's defects.

1. Pub. L. No. 90-618,82 Stat. 1213 (codified as amended at 18 U.S.C. $\$ \S 921-928$ (1982); 18 U.S.C. app. $\$ \S 1201-1203$ (1982); 26 U.S.C. $\$ \S 5801-5872$ (1982)). Many of these same provisions were enacted as part of the Omnibus Crime Control and Safe Streets Aci of 1968. Pub. L. No. 90351, 82 Stat. 197 (codified as amended in scattered sections of titles 5, 18,42, and 47 of the U.S. Code (1982)).

2. United States v. Biswell, 406 U.S. 311 (1972); United States v. Bass, 404 U.S. 336 (1971); United States v. Freed, 401 U.S. 601 (1971).

3. United States v. Biswell, 406 U.S. $311,313-17$ (1972).

4. United States v. Freed, 401 U.S. 601, 605-07 (1971). 
questions regarding act $^{5}$ and mental requirements. ${ }^{6}$ In both contexts, its resolution of these matters ran the gamut from restrictive to permissive. Although the Court probably recognized the relevance of limiting overzealous law enforcement in its applications of the fourth and fifth amendments, it was seemingly unaware that the regulative concerns of enforcement should have informed its statutory constructions as well. One goal of this article is to sensitize judges and advocates to the kinds of considerations the Court seems to have overlooked.

Because of our confused attitudes toward gun control legislation, such laws are a particularly apt subject for a study of strict construction. While a majority of Americans apparently favor gun control in some form, ${ }^{7}$ the substantial minority of gunholders remain vigorously opposed even to legislation that would not seem to affect them. ${ }^{8}$ One hypothesis for this staunch opposition is that gunholders fear expansive judicial interpretations of gun control statutes and the overreaching by law enforcement personnel which, they believe, would surely follow such interpretations. ${ }^{9}$ The rule of strict construction addresses this fear directly by promising limited interpretations of enacted statutes.

The widespread belief in a constitutional right to bear arms adds further interest to the study of strict construction of gun control legislation. Regardless of the varied perceptions regarding the presumed source of this right-whether the federal ${ }^{10}$ or a state constitution ${ }^{11}$ or the general right to

5. United States v. Bass, 404 U.S. 336, 339-47 (1971).

6. United States v. Freed, 401 U.S. 601,607 (1971).

7. J. Wright, P. Rossi \& K. Daly, Under the Gun: Weapons, Crime, and Violence in AMERICA $240 \&$ n. 15 (1983).

8. Id. at 239 .

9. The overzealous enforcement of gun licensing laws gives credence to this hypothesis. See Bruce-Briggs, The Great American Gun War, 45 PuB. InTERest 37, 43-44 (1976). Bruce-Briggs concluded that this enforcement history "suggests to the organized gun owners that licensing systems are a screen not against criminals but against honest citizens, and that licensing authorities are not to be trusted with any sort of discretionary power." Id. at 44. See also Hardy \& Chotiner, The Potential for Civil Liberties Violations in the Enforcement of Handgun Prohibition, in Restricting Handguns: The Liberal Skeptics Speak Out 194, 211 (D. Kates ed. 1979) ("Under existing statutes, broad discretion is generally given and cheerfully abused.') [hereinafter cited as Restricting HaNDGUNS].

10. U.S. Const. amend. II; see Staff of Subcomm. on the Constitution of the Senate Comm. on the Judiciary, 97th Cong., 2d Sess., The Right to Keep and Bear Arms (Comm. Print 1982) [hereinafter cited as STAFF REPorT].

$[T]$ he history, concept, and wording of the second amendment . . . as well as its interpretation by every major commentator and court in the first half-century after its ratification, indicates that what is protected is an individual right of a private citizen to own and carry firearms in a peaceful manner.

StafF REPORT, supra, at 12. For an exhaustive exposition and defense of this view, see Kates, Handgun Prohibition and the Original Meaning of the Second Amendment. 82 Mich. L. REv. 204 (1983). For articles taking the opposite view, see id. at $207 \mathrm{n} .13$.

11. See Staff RePort, supra note 10, at 14-15 (citing the following cases finding a right to bear arms under state constitutional law: City of Lakewood v. Pillow, 180 Colo. 20, 501 P.2d 744 (1972): Schubert v. DeBard, 398 N.E.2d 1339 (Ind. App. 1980); Taylor v. McNeal, 523 S.W.2d 148 (Mo. App. 1975); City of Las Vegas v. Moberg, 82 N.M. 626, 485 P.2d 737 (Ct. App. 1971): State v. Kessler, 289 Or. 359, 614 P.2d 94 (1980)). For a detailed analysis, see Caplan, The Right of the Individual to Bear Arms: A Recent Judicial Trend, 1982 DET. C.L. REv. 789; Dowlut \& Knoop, Stale Constitutions and the Right to Keep and Bear Arms, 7 Okla. City U.L. Rev. 177 (1982). 
defend oneself and one's family ${ }^{12}$-it is incontrovertible that a large majority of Americans believe that they do have the right to possess weapons. ${ }^{13}$ The perception that gun ownership is protected behavior dramatically affects the enforceability of gun control statutes. Given the large volume of firearms in private hands, ${ }^{14}$ the effectiveness of any far-reaching gun control initiative depends on voluntary compliance; believers in a right to bear arms are significantly less likely to comply. ${ }^{15}$ Because of its importance to the enforcement of gun control statutes, the perception of a right to possess weapons should be a factor in the interpretation of such statutes.

Also relevant to strict construction is the history of gun control as a tool of discrimination. The earliest American gun control statutes were directed at blacks and immigrants, ${ }^{16}$ and modern opponents of gun control have emphasized its potential for aiding racism and sexism. ${ }^{17}$ Beyond discrimination against recognized minorities is the question of invidious treatment of the "gun subculture";18 there is much evidence that members of the nongunholding population consider discrimination against gun owners commendable. ${ }^{19}$ Strict construction is a device for limiting the discriminatory use of criminal statutes against any identifiable minority.

A final reason to examine strict construction of gun legislation is reflected in the set of relatively recent publications expressing second thoughts about the wisdom of gun control laws. Criminologists and criminal law theorists, including former gun control supporters, have argued that the crime-reducing potential of gun control has been exaggerated ${ }^{20}$ and that its potential

12. See Kates, Can We Deny Citizens Both Guns and Protection?, Wall St. J., Aug. 17, 1983, at 22, col. 4.

13. J. WRIGHT, P. Rossi \& K. DALY, supra note 7, at 238-39.

14. See id. at 43 (between 100 million and 140 million in the United States).

15. See Kates, Handgun Banning in Light of the Prohibition Experience, in Firearms and VIOLENCE: Issues of Regulation 139, 155-60 (D. Kates ed. 1984).

16. See L. Kennett \& J. Anderson, The Gun in America 50 (1975); Kates, Toward a History of Handgun Prohibition in the United States, in Restricting Handguns, supra note 9, at 7, 15-22; Kessler, Gun Control and Political Power, 5 LAw \& PoL'y Q. 381, 382 (1983).

17. Salter \& Kates, The Necessity of Access to Firearms by Dissenters and Minorities 11 hom Govermment Is Unwilling or Unable to Protect, in Restricting Handguns, supra note 9, at 185; Silver \& Kates. SelfDefense, Handgun Ownership, and the Independence of Women in a Violent, Sexist Society, in Restricting Handguns, supra note 9, at 139.

18. See J. Wright, P. Rossi \& K. Daley, supra note 7, at 323-24. Linder the Gun ends by raising the following questions:

A critical issue in modern America is whether the doctrine of cultural pluralism should or should not be extended to cover the members of the gun subculture. Is this cultural pattern akin to the segregationism of the South that was broken up in the interest of the public good? Or, is it more akin to those subcultures that we have recognized as legitimate and benign forms of selfcxpression?

Id. at 324 .

19. See Tonso, Social Science and Sagecraft in the Debate over Gun Control, 5 LAw \& Pol'Y Q. 325. 326. 33 (1983); see also L. KenNeTt \& J. Anderson, supra note 16, at 254-55; Bruce-Briggs, supra note 9. at 61 .

20. J. WRigut, P. Rossi \& K. DAly, supra note 7, at 319-24; see Bruce-Briggs, supra note 9. al 60; Kleck \& Bordua, The Factual Foundation for Certain Key Assumptions of Gun Control, 5 Law \& Poi.' $Y$ Q. 271. 272-74 (1983); Silver \& Kates, supra note 17, at 151-58; Tonso, supra note 19, at 339-40. 
enforcement costs are high. ${ }^{21}$ Given this dubiety regarding the effectiveness of gun legislation, courts should be even more hesitant to extend a gun control statute to a case outside the core meaning of that statute.

This article's study of strict construction of gun control statutes has three parts. Part II generally explains the rule of strict construction and its function as a limit on arbitrary and discriminatory enforcement. Part III describes the Gun Control Act of 1968 and the first three Supreme Court decisions interpreting the 1968 Act. Part IV examines the lower federal courts' subsequent use of these decisions in order to show some of the costs resulting from the Court's failure to impose adequate limits on law enforcement.

\section{II \\ Constitutionally Imposed Limits on ENForcement AND Prosecutorial Discretion}

Strict construction of penal statutes in favor of the defendant is one of a trio of doctrines that limit overzealous enforcement of criminal laws. ${ }^{22}$ Along with the principle of legality (the concept that crimes must have been defined prior to their enforcement), ${ }^{23}$ and the void-for-vagueness doctrine,${ }^{24}$ the rule of strict construction not only assures more complete notice of the prohibitions of the criminal law, ${ }^{25}$ but also limits the ability of police and prosecutors to use that law to harass and intimidate the public.

In The Limits of the Criminal Sanction, ${ }^{26}$ Herbert Packer outlined the impact of these three doctrines on criminal law enforcement. Eschewing the customary explanation of the principle of legality-that it maintains the separation of powers between legislature and judiciary ${ }^{27}$ - Packer argued that the principle's most important function is "to prevent abuses of official discretion" 28 by those who commence the criminal process, that is, by police officers and prosecutors. "[I]n a system that lodges the all-important

21. Hardy \& Chotiner, supra note 9, at 202-09; Kaplan, Controlling Firearms, 28 CLEv. ST. L. REv. 1,11 (1979); Kaplan, The Wisdom of Gun Prohibition, 455 Annals 11, 15-19 (1981); Kates, supra note 15, at 160-64; Kessler, Enforcement Problems of Gun Control: A Victimless Crimes Analysis, 16 CRIM. L. BuLL. 131, 146-47 (1980).

22. See generally P. Low, J. Jefrries \& R. Bonnie, Criminal Law 31-112 (1982). Part II of this article draws heavily on Low, Jeffries, and Bonnie's analysis (though it is clear that they would not support many of its more enthusiastic claims for the rule of strict construction). See also Jeffries, Legality, Vagueness, and the Construction of Penal Statutes, 71 VA. L. REv. 189 (1985).

23. See generally J. Hall, General Principles of Criminal. Law 27-69 (2d ed. 1960).

24. See generally Note, The Void-for-Vagueness Doctrine in the Supreme Court, 109 U. PA. L. REv. 67 (1960) (authored by Professor Anthony Amsterdam).

25. McBoyle v. United States, 283 U.S. 25 (1931), is a celebrated example of the notice function of the rule of strict construction. The McBoyle Court, through Justice Holmes, held that an airplane was not a "motor vehicle" within the meaning of a federal statute prohibiting interstate transportation of stolen motor vehicles. "[F]air warning should be given to the world in language that the common world will understand, of what the law intends to do if a certain line is passed." Id. at 27. The same reasoning also explains the notice functions of the requirements of a previously stated, unambiguous definition of the crime.

26. H. Packer, The Limits of the Criminal Sanction 79-102 (1968).

27. See, e.g., Keeler v. Superior Court, 2 Cal. 3d 619, 631-32, 470 P.2d 617, 624-25, 87 Cal. Rptr. $481,488-89$ (1970).

28. H. PACker, supra note 26. at 85. 
initiating power in the hands of officials who operate, as they must, through informal and secret processes, there must be some devices to insure that the initiating decisions are, to the greatest extent possible, fair, evenhanded, and rational." 29 Though a number of trial-related mechanisms serve to maximize evenhandedness, ${ }^{30}$ Packer argued that "the most important single device is the requirement . . . that the police and prosecutors confine their attention to the catalogue of what has already been defined as criminal." 31

The void-for-vagueness doctrine limits arbitrary enforcement in much the same way. A vague criminal statute offers law enforcement personnel opportunities for selective interpretation, harassment, and intimidation. The primary vice of an ambiguous statute, therefore, is not that it delegates too much lawmaking power to the courts, but that it delegates too much lawenforcing discretion to police and prosecutors. ${ }^{32}$ This line of reasoning in support of the void-for-vagueness doctrine lies at the heart of Papachristou $v$. City of Jacksonville, ${ }^{33}$ in which the Court struck down a municipal vagrancy statute used to arrest two white women and two black men traveling together in an automobile. ${ }^{34}$ "Of course, vagrancy statutes are useful to the police . . . ," the United States Supreme Court admitted, "[b]ut the rule of law implies equality and justice in its application. Vagrancy laws of the Jacksonville type teach that the scales of justice are so tipped that evenhanded administration of the law is not possible." 35

As Papachristou demonstrated, the void-for-vagueness doctrine has constitutional force ${ }^{36}$ as does the principle of legality. ${ }^{37}$ This force varies considerably, however, depending on the type of person likely to be harassed and the type of conduct likely to be intimidated. A vague statute that invites, or at least is challenged in a context suggesting, racially discriminatory

29. Id. at 89. On the necessary secrecy of police and prosecutorial activities, see id.

30. Examples include a subsequent judicial determination of probable cause to arrest, Gerstein v. Pugh, 420 U.S. 103, 112-13 (1975); the requirement of a grand jury indictment, see U.S. CONST. amend. $V$; and the disallowance of prosecutions based on impermissible prosecutorial motives, see Blackledge v. Perry, 417 U.S. 21, 27 (1974).

31. H. PACKer, supra note 26, at 90 . To illustrate the principle of legality at work, Packer noted that when LSD became a drug of choice in the mid-1960's, law enforcement personnel largely delayed policing the drug's use until specific legislative prohibitions were enacted. Id.

32. Packer described the void-for-vagueness doctrine as

an injunction [to the legislature] to take care in the framing of criminal statutes that no more power be given to call conduct into question as criminal, with all the destruction of human autonomy that this power necessarily imports, than is reasonably needed to deal with the conduct the lawmakers seek to prevent.

Id. at 94-95.

33. 405 U.S. 156 (1972).

34. The four were charged with "vagrancy-'prowling by auto." 405 U.S. at 158 . Other defendants, whose cases were consolidated in Papachristou, were charged as "vagabond $[\mathrm{s} \mid$, , as "common thie|ves]," or for "loitering." Id.

35. 405 U.S. at 171.

36. The due process clauses of the fifth and fourteenth amendments provide the constitutional basis for the vagueness doctrine.

37. The ex post facto clause, U.S. Const. art. I, 89 , cl. 3, prohibits not only retroactive criminal statutes, but also (with the aid of the due process clause, see supra note 36 ) unforesceable judicial enlargements of existing statutes. See Bouie v. City of Columbia, 378 U.S. 347, 352-53 (1964). 
enforcement is more likely to be voided; so too, as Packer noted, are statutes "in which the threat of enforcement discretion has been perceived as impinging on constitutionally protected values such as freedom of speech and of the press." 38

These facets of analysis under the principle of legality and the vagueness doctrine-concern over arbitrary and discriminatory enforcement, and heightened scrutiny when protected classes or protected freedoms are involved-also emerge during examination of the rule of strict construction of penal statutes, which Packer labeled "something of a junior version of the vagueness doctrine."39 Like the prohibition against vague statutes, the prescription that criminal laws be construed in favor of the defendant limits the range of discretion of those who enforce the law. Consider Keeler $v$. Superior Court, ${ }^{40}$ which held that a brutal feticide was not murder because a viable but unborn fetus was not a "human being" within the meaning of California's murder statute. This result can be justified as a minimization of the opportunities for inventiveness available to prosecutors and police officers in their enforcement of the criminal laws. ${ }^{41}$

As a limit on arbitrary enforcement, the rule of strict construction derives some of its force from constitutional law (though the rule's constitutional underpinnings are by no means as clear as those of the principle of legality and the vagueness doctrine).$^{42}$ The rule's constitutional force is shown by its resilience in the face of legislative attempts to abrogate the strict construction principle. ${ }^{43}$ Such attempts have had only checkered success; courts frequently ignore abrogating statutes or render them impotent through judicial construction.44 "[D]espite American legislative efforts to eliminate strict interpretation and to have penal statutes construed like civil ones," Jerome

38. H. PACKer, supra note 26, at 94. Bouie v. City of Columbia, 378 U.S. 347 (1964), show's the same reasoning at work in the context of the principle of legality. On appeal from trespass convictions against civil rights demonstrators, a state supreme court enlarged the definition of trespass (from entry after notice to failure to leave after notice). 378 U.S. at 350 . The United States Supreme Court reversed the convictions. Id. at 349.

39. H. PACKER, supra note 26 , at 95.

40. 2 Cal. 3d 619, 470 P.2d 617, 87 Cal. Rptr. 481 (1970).

41. The Keeler court relied more heavily on the fair notice function of the role of strict construction, id. at 633-39, 470 P.2d at 626-30, 87 Cal. Rptr. at 490-94; see supra note 25, an approach strongly criticized in the Keeler dissent, id. at 644-45, 470 P.2d at 633-34, 87 Cal. Rptr. at 497-98 (Burke, Acting C.J., dissenting). Packer noted the tendency, in the context of the principle of legality, to present arbitrary enforcement arguments in terms of fair notice:

The "fair notice" rationale is a prophylactic rationale for tomorrow's hard case rather than today's casy one. It represents a reaction that is one of the most characteristic and ingrained responses in the human situation and therefore in the law: if we let you do this, how do we know that you won't use it as a justification for doing something we wouldn't want you to do?

H. Packer, supra note 26, at 85; see also id. ("[I]t is not . . that this man . . . is being unfairly taken by surprise. It is that if we let you do this to these fellows, who so richly deserve it, how do we know that you won i do it to us?") (emphasis in original).

42. See supra notes $36-37$.

43. The capstone of these attempts is Model Penal Code $\S 1.02(3)$ (1962): "The provisions of this Code shall be construed according to the fair import of their terms . . . .

44. See Hall, Strict or Liberal Consiruction of Penal Statutes, 48 HARV. L. REv. 748, $754-56$ (1935) (deploring such decisions). For a more recent example, see Keeler v. Superior Court, 2 Cal. $3 \mathrm{~d}$ at 632, 470 P.2d at 625, 87 Cal. Rptr. at 489; see also infra note 47. 
Hall noted, "strict interpretation continues to prevail in American penal law." 45 Other than characterizing this trend as naked judicial usurpation, ${ }^{46}$ the only possible explanation is that the rule of strict construction derives at least some of its power from a source not subject to statutory changespecifically, constitutional law. ${ }^{47}$

Of course, courts do not always construe criminal statutes strictly, or as strictly as possible. ${ }^{48}$ The impact of liberal construction on protected classes and protected freedoms has much to do with this variation. Thus, one consideration probably on the minds of the Keeler majority (though not voiced in their opinion) was the potential impact of a contrary holding on persons obtaining and performing abortions under California's then quite liberal abortion law. ${ }^{49}$ If killing a viable fetus had been held to be murder, what would prevent a prosecutor from filing murder charges against those who conspired to end the life of a nonviable but healthy fetus-its mother and her doctor?50 And even if no such prosecution ever occurred, would its mere possibility deter some women from seeking abortions and some physicians from performing them? ${ }^{51}$ Assuming that the Keeler majority accepted abortion as protected conduct under state (if not federal) law, ${ }^{52}$ the desire to shelter such conduct may well have contributed to that court's strict construction of California's murder statute. ${ }^{53}$

45. J. HALL, supra note 23 , at 48 .

46. The usurpation explanation would be decidedly odd. Under it, the courts would be overstepping the bounds of their authority to interpret statutes in order to strike down a law that enlarged their authority to interpret statutes.

47. See, e.g., Keeler v. Superior Court, 2 Cal. $3 \mathrm{~d}$ at 632-33, 470 P.2d at 625-26, 87 Cal. Rptr. at 489-90. The Keeler court refused to apply California's statutory command to construe its criminal laws "according to the fair import of their terms," Cal. Penal Code $\$ 4$ (West 1970), because following the statute on the Keeler facts would have created separation-of-powers problems: the court would necessarily have engaged in legislating. The court also offered a due-process-based argument for not following the fair import statute. 2 Cal. $3 \mathrm{~d}$ at $633-39,470$ P.2d at 626-30, 87 Cal. Rptr. at 490-94.

48. See, e.g., People v. Ashley, 42 Cal. 2d 246, 262-65, 267 P.2d 271, 281-83 (extending crime of obtaining property by false pretenses to obtaining property by misrepresentation of future intention), cert. denied, 348 U.S. 900 (1954); People v. Sobiek, 30 Cal. App. 3d 458, 468, 106 Cal. Rptr. 519, 525 (extending theft to partnership property expropriated by partner), cert. denied, 414 U.S. 855 (1973).

49. Cal. Health \& Safety Code $\$ \S 25950-25957$ (West 1984) (adopted 1967). Keeler preceded Roe v. Wade, 410 U.S. 113 (1973), by three years.

50. This is a variant of the "slippery slope" argument offered by Packer in favor of the principle of legality. See supra note 41 .

51. Although most frequently encountered in the context of vagueness and freedom of expression, see, e.g., NAACP v. Button, 371 U.S. 415, 432-33 (1963), this sort of "chilling effect" argument is clearly applicable to the rule of strict construction of penal statutes and the right to an abortion.

52. See supra note 49.

53. The lack of adverse impact on protected behavior in cases like People v. Ashley, 42 Cal. 2d 246, 267 P.2d 271 (extending crime of obtaining property by false pretenses to obtaining property by misrepresentation of future intention), cert. denied, 348 U.S. 900 (1954), and People v. Sobiek, 30 Cal. App. 3d 458, 106 Cal. Rptr. 519 (extending theft to partnership property expropriated by partncr). cert. denied, 414 U.S. 855 (1973), renders more tolerable those cases' liberal construction of penal statutes. 
The rule of strict construction is not without its detractors. ${ }^{54}$ In 1935, Livingston Hall argued that it was the rampant use of capital punishment in seventeenth and eighteenth century England that had caused strict construction to flourish; consequently, the advent of more proportionate sentencing should have rendered the doctrine an anachronism. ${ }^{55}$ But even Livingston Hall would have required strict construction in some circumstances: "[T]his does not mean that all penal statutes should be liberally construed. Political liberty does require that people should be able to pursue certain types of conduct with definite assurance of the bounds of criminal liability." 56 The examples Hall gave to support this assertionmostly crimes affecting commercial and sporting activities ${ }^{57}$-reflect a 1935 concept of protected behavior; nevertheless, the assertion demonstrates that even an opponent of strict construction recognized the need for such a rule in the context of protected conduct.

Livingston Hall's "weak" form of strict construction is followed in some American jurisdictions, while others employ a stronger version, recognizing few exceptions to the rule. Potent arguments in favor of the "strong" form of strict construction have been made, most notably by Jerome Hall. ${ }^{58}$ The federal courts' "rule of lenity" in interpreting congressional enactments arguably places the United States in the latter category, ${ }^{59}$ though the actions of those courts (including the Supreme Court in its construction of the Gun Control Act of 1968) frequently belie this conclusion.

\section{III}

\section{The Gun Control Act of 1968}

The Gun Control Act of 1968 imposes criminal penalties under three separate sets of provisions. ${ }^{60}$ The 1968 Act amended chapter 44 of title 18 of the United States Code to prohibit numerous firearms-related activities. Section 922 of title 18 makes it unlawful for any person: (1) to knowingly make a false statement or to furnish false identification in attempting to

54. See, e.g., Keeler v. Superior Court, 2 Cal. $3 \mathrm{~d}$ at $641-42,470$ P.2d at $631-32,80$ Cal. Rptr. at 495-96 (Burke, Acting C.J., dissenting).

55. Hall, supra note 44 , at 749-51.

56. Id. at 761 (emphasis in original); see id. at 762-68 (strict construction appropriate to prevent a disproportionate penalty, to avoid criminalizing honest attempts at compliance, and to reflect changed social conditions).

57. Id. at 761-62 n.66. Although two of the cases cited by Hall concern hunters, both involve violations of hunting season limitations rather than firearms offenses.

58. See J. HALL, supra note 23 , at 47 ("The principle of legality enjoins the judge . . to resolve his doubts in favor of the accused."); see also Hall, Police and Law in a Democratic Societ?. 28 IND. L.J. $133,170-77$ (1953) (relating strict construction to constitutional limits on police discretion).

59. See United States v. Universal C.I.T. Credit Corp., 344 U.S. 218, $221-22$ (1952) ("when |a| choice has to be made between two readings of what conduct Congress has made a crime, it is appropriate, before we choose the harsher alternative, to require that Congress should have spoken in language that is clear and definite"); see also United States v. Wiltberger, 18 U.S. (5 Wheat.) 76, 95 (1820).

60. See generally Zimring, Firearms and Federal Latw: The Gun Control Ad of 1968, 4 J. Legal. Stud. $133,148-57(1975)$. 
acquire a firearm or ammunition;61 (2) to ship, transport, or receive a firearm or ammunition in interstate commerce if one has been indicted for or convicted of a felony; is a fugitive from justice; is an unlawful addict or user of depressants, stimulants, or narcotics, or has been adjudicated mentally defective or committed to a mental institution; 62 (3) to transport, receive, store, dispose of, or pledge as security for a loan a stolen firearm or stolen ammunition moving in interstate commerce, knowing or having reason to know the firearm or ammunition is stolen; 63 (4) to transport or receive in interstate commerce any firearm with an altered serial number; 64 or (5) to knowingly import a firearm or ammunition into the United States without an appropriate permit or to knowingly receive a firearm or ammunition so imported. ${ }^{65}$ Section 922 also criminalizes knowingly delivering a package containing a firearm or ammunition to a common carrier for interstate transport without written notice of the package's contents, as well as criminalizing the carrier's transport of the package if the carrier knows or has reason to know that its shipment is illegal. ${ }^{66}$

For those who are not licensed to transact in firearms and ammunition, it is a crime under section 922: (1) to import, manufacture, or deal in firearms or ammunition or to ship, transport, or receive a firearm or ammunition in interstate commerce; 67 (2) to transport into one's home state or to receive there a firearm obtained from outside the state; 68 or (3) to transfer a firearm to a person who resides in another state, unless that person has a license to conduct firearms transactions. ${ }^{69}$ Section 922 also prohibits nonlicensees from transporting in interstate commerce certain highly effective firearms and "destructive devices," unless an appropriate permit is obtained. ${ }^{70}$

For licensed importers, manufacturers, dealers, and collectors of firearms or ammunition, section 922 criminalizes the following acts: (1) transporting, in interstate commerce and to a nonlicensee, any firearm or ammunition; ${ }^{71}$ (2) selling or delivering a firearm or ammunition to persons who the licensee knows or has reason to know either are underage or do not reside in the state

61. 18 U.S.C. $\$ 922(a)(6)$ (1982). The provision applies to acquisition only from those licensed to deal in firearms and ammunition.

62. 18 U.S.C. $\$ 922(\mathrm{~g})-(\mathrm{h})$ (1982). The subsections use the term "crime punishable by imprisonment for a term exceeding one year" instead of "felony." "Depressant," "stimulant," and "narcotic" are defined by reference to other statutes.

63. 18 U.S.C. $\$ 922(\mathrm{i})-(\mathrm{j})(1982)$.

64. 18 U.S.C. $\$ 922(\mathrm{k})(1982)$.

65. 18 U.S.C. $\$ 922(l)$ (1982). The permit procedure is outlined in 18 U.S.C. $\$ 925$ (d) (1982).

66. 18 U.S.C. $\$ 922(\mathrm{e})$-(f) (1982). The provision does not apply to shipments to licensed firearms and ammunitions dealers.

67. 18 U.S.C. $\S 922(a)(1)(1982)$.

68. 18 U.S.C. $\$ 922(a)(3)$ (1982). The subsection exempts firearms acquired by bequest or intestate succession, as well as firearms obtained pursuant to the exceptions in 18 U.S.C. $\S 922$ (b)(3) (1982). For the exceptions, see infra note 72.

69. 18 U.S.C. $\$ 922(a)(5)$ (1982). The transferor must know or have reason to know that the transferee resides in another state.

70. 18 U.S.C. $\$ 922(a)(4)$ (1982). See generally infra text accompanying notes 84-85.

71. 18 U.S.C. $\$ 922(a)(2)$ (1982). The subsection exempts transportation associated with repairing or customizing firearms. 
of the licensee's place of business; ${ }^{72}$ (3) selling or delivering a firearm or ammunition without the required recordation or when the disposition would violate an applicable state or local law; ${ }^{73}$ (4) selling or delivering a firearm or ammunition to a person who has been indicted for or convicted of a felony; who is a fugitive from justice; who is an unlawful addict or user of depressants, stimulants or narcotics; or who has been adjudicated mentally defective or committed to a mental institution; ${ }^{74}$ and (5) knowingly falsifying or omitting to make any required record of a firearms or ammunition transaction. ${ }^{75}$ Under section 922 licensees are also forbidden to sell or deliver specified firearms and destructive devices, unless appropriate permits are obtained. ${ }^{76}$

Section 923 establishes numerous recordkeeping requirements for those licensed to transact in firearms and allows access to their premises by federal inspectors. ${ }^{77}$ Section 924 renders any violation of section 922 punishable by five years' imprisonment, a fine of $\$ 5,000$, or both. ${ }^{78}$ The section also authorizes an additional sentence of from one to ten years for any federal crime committed with a firearm. ${ }^{79}$

The second set of criminal penalties imposed by the 1968 Act were amendments to the appendix to title 18 of the federal code. Section 1202 inculpates a person who receives, possesses, or transports a firearm in interstate commerce and who: (1) has been convicted of a felony, dishonorably discharged, or adjudged mentally incompetent; (2) has renounced his United States citizenship; or (3) is an alien illegally within the United States. ${ }^{80}$ The section also makes it a crime for any employee of a

72. 18 U.S.C. $\$ 922(b)(1),(3)$ (1982). One must be at least 18 years old to receive a shotgun, rifle, or shotgun or rifle ammunition and at least 21 to receive any other firearm or ammunition. 18 U.S.C. $\S 922(\mathrm{~b})(1)(1982)$.

Subsection (b)(3), pertaining to sales to nonresidents, does not apply to a resident of a state contiguous to the state of the licensee's place of business, if the sale satisfies the legal requirements of both states. Nor does the subsection apply to temporary rentals for sporting purposes or to sales of shotguns or rifles to out-of-state hunters and sport shooters who are replacing lost weapons. 18 U.S.C. $\$ 922$ (b)(3) (1982). The subsection is also inapplicable to transactions between licensees. 18 U.S.C. § 922(b) (1982).

73. 18 U.S.C. $\$ 922(b)(2)$, (5) (1982). Regarding recordkeeping requirements, see 18 U.S.C. $\S \S 922(\mathrm{c}), 923$ (1982). Subsection (b) (2), concerning sales in violation of nonfederal law, exempts licensees who reasonably believed the sales were not unlawful. 18 U.S.C. $\S 922(b)(2)$ (1982). The subsection does not apply to transactions between licensees. 18 U.S.C. $\$$ 922(b) (1982).

74. 18 U.S.C. $\$ 922$ (d) (1982); see supra note 62. The licensee must know or have reason to know that the recipient falls into one of the listed categories. Subsection (d) does not apply if the recipient is a licensee who obtains or retains his license despite a felony conviction or indictment, pursuant to 18 U.S.C. $\$ 925$ (b) - (c) (1982).

75. 18 U.S.C. $\$ 922(\mathrm{~m})(1982)$. Regarding recordkeeping requirements, see 18 U.S.C. $\S \S 922(\mathrm{c}), 923(1982)$.

76. 18 U.S.C. $\$ 922(b)(4)$ (1982). See generally infra text accompanying notes 84-85.

77. 18 U.S.C. $\$ 923(\mathrm{~g})(1982)$.

78. 18 U.S.C. $\$ 924(\mathrm{a})$ (1982).

79. 18 U.S.C. $\$ 924$ (c) (1982). A second violation of the subsection justifies a mandatory consecutive sentence of from two to 25 years. Id.

80. 18 U.S.C. app. $§ 1202(a)$ (1982). "Felony" includes all crimes punishable by imprisonment for more than one year, except those crimes labeled misdemeanors that do not involve a firearm and are not punishable by more than two years' imprisonment. 18 U.S.C. app. $\$ 1202$ (c) () (1982). 
person who satisfies one of these three criteria to receive, possess, or transport a firearm in interstate commerce. ${ }^{81}$ The penalty for violating section 1202 is two years' imprisonment, a $\$ 10,000$ fine, or both. ${ }^{82}$

The third set of criminal provisions in the Gun Control Act of 1968 amended the National Firearms Act of $1934 .^{83}$ The 1934 Act, in the words of Franklin Zimring, "was a concentrated attack on civilian ownership of machine guns, sawed-off shotguns, silencers, and other relatively rare firearms that had acquired reputations as gangster weapons during the years preceding its passage." 84 The 1968 Act extended this provision to include other similar weapons and "destructive devices;" 85 the amendments also removed a registration requirement that the Supreme Court had voided, on selfincrimination grounds, earlier in 1968.86

The 1968 Act also reorganized the criminal provisions of the earlier legislation in section 5861 of the Internal Revenue Code. Section 5861 declares it unlawful for a person: (1) to manufacture, import, or deal in the specified weapons without registering and paying the necessary $\operatorname{tax} ;{ }^{87}$ (2) to make or transfer a specified weapon without paying the necessary tax or to receive or possess a weapon so made or transferred;8 (3) to receive or possess a specified weapon that is not registered to him;89 (4) to alter the serial number of a specified weapon or to receive or possess a weapon so altered; ${ }^{90}$ and (5) to knowingly make a false entry on any required record pertaining to a specified weapon. ${ }^{91}$ The penalty for violating section 5861 is ten years' imprisonment, a $\$ 10,000$ fine, or both. ${ }^{92}$

The criminal provisions of the 1968 Act are complex, overlapping, and frequently technical. Unfortunately, in such a legislative scheme, federal agents and prosecutors can easily find opportunities for harassment and intimidation of the firearm-holding populace. ${ }^{93}$ One responsibility of the courts is to limit these opportunities for arbitrary enforcement by strictly construing the provisions of the 1968 Act in favor of the criminal defendant;

81. 18 U.S.C. app. $\$ 1202$ (b) (1982).

82. 18 U.S.C. app. $\$ 1202(\mathrm{a})$-(b) (1982).

83. Ch. 757,48 Stat. 1236 (current version at 26 U.S.C. $\$ \$ 5801-5872$ (1982)).

84. Zimring, supra note 60 , at 138 .

85. Pub. L. No. $90-618, \S 201,82$ Stat. 1213,1230 (codified as amended at 26 U.S.C. $\$ 5845$ (1982)).

86. See Haynes v. United States, 390 U.S. 85, 95-99 (1968).

87. 26 U.S.C. $\$ 5861$ (a) (1982). For the registration and tax requirements, see 26 U.S.C. $\S \S 5801-5802$ (1982).

88. 26 U.S.C. $\$ 5861$ (b)-(c), (e)-(f) (1982); see also 26 U.S.C. $\$ 5861$ (k) (1982) (unlawful to receive or transfer specified weapon that has been illegally imported).

89. 26 U.S.C. $\$ 5861$ (d) (1982); see also 26 U.S.C. $\$ 5861(j)$ (1982) (unlawful to transport, deliver, or receive in interstate commerce specified weapon that is unregistered).

90. 26 U.S.C. $\$ 5861(\mathrm{~g})-(\mathrm{h})(1982)$.

91. 26 U.S.C. $\$ 586 I(1)(1982)$.

92. 26 U.S.C. $\$ 5871$ (1982).

93. See Staff Report, supia note 10, at 20 ("it is apparent that enforcement tactics made possible by current federal firearms laws are constitutionally, legally, and practically reprehensible"); see also Bruce-Briggs, supra note 9, at 48-49. For a polemical exposition of the same viewpoint, see Task Force to Investigate the Enforcement Policies of the Burfau of Aicohol. Tobacco and Firearms, The BATF's War on Civil Liberties (1979) [hercinafter cited as Task Force]. 
in the federal system, this responsibility lies ultimately with the Supreme Court.

\section{A. Supreme Court Interpretation-United States $v$. Freed}

The first prosecution under the 1968 Act to reach the Supreme Court was United States v. Freed. ${ }^{94}$ The government had charged Donald Freed and Shirley Sutherland with possession of unregistered hand grenades in violation of section 5861 of the Internal Revenue Code $^{95}$ and with conspiracy to possess these weapons. ${ }^{96}$ Defendants successfully moved to dismiss the indictment, claiming both that registering the hand grenades would have compelled them to incriminate themselves and that the indictment was fatally deficient because it failed to allege that the defendants knew the hand grenades were unregistered. ${ }^{97}$

The defendants' first argument derived from Haynes $v$. United States, ${ }^{98}$ which had held that assertion of the fifth amendment's privilege against selfincrimination was a valid defense to allegations of failure to register under the National Firearms Act of 1934,99 one of the 1968 Act's predecessor statutes. ${ }^{100}$ In enacting the 1968 Act, Congress had attempted to avoid the self-incrimination problems noted in Haynes by prohibiting the government's use of information provided in accordance with the Act in any prosecution "with respect to a violation of law occurring prior to or concurrently with the filing of [the information]."101 Freed and Sutherland argued that because the statute continued to permit use of the required information in the prosecution of subsequent crimes, the registration requirement still compelled them to incriminate themselves. ${ }^{102}$

This argument found support in the companion case to Haynes, Marchettiv. United States. ${ }^{103}$ In Marchetti, which provided a self-incrimination defense to wagering tax and registration prosecutions, the Court, through Justice Harlan, noted that the information requirement posed self-incrimination problems with regard to future acts, as well as past and present ones: "The hazards of incrimination . . . as to future acts are not trifling or imaginary. Prospective registrants can reasonably expect that registration and payment of the occupational tax will significantly enhance the likelihood of their prosecution for future acts, and that it will readily provide evidence which will

\footnotetext{
94. 401 U.S. 601 (1971).

95. 26 U.S.C. $\$ 5861$ (d) (1982); see supra text accompanying note 89.

96. 18 U.S.C. $\$ 371$ (1982).

97. 401 U.S. at 604-05.

98. 390 U.S. 85 (1968).

99. Ch. 757, 48 Stat. 1236 (current version at 26 U.S.C. $\$ \$ 5801-5872$ (1982)); spe supra text accompanying notes $83-84$.

100. Haynes, 390 U.S. at 99; see Marchetti v. United States, 390 U.S. 39, 50-54 (1968) (recognizing similar defense to wagcring tax and registration prosecutions).

101. 26 U.S.C. $\$ 5848$ (1982).

102. 401 U.S. at 606-07.

103. 390 U.S. 39 (1968).
} 
facilitate their convictions."104 In the case of Freed and Sutherland, it is not too farfetched to suppose that registration of the hand grenades would have drawn the attention of law enforcement officials and that the information so provided would have been useful in convicting Freed and Sutherland of any subsequent crime involving the use of hand grenades.

Though the district court accepted this argument, the Supreme Court on direct appeal unanimously reversed. ${ }^{105}$ Justice Douglas' opinion for the Court relied on the Solicitor General's representation that, as a matter of administrative policy, none of the registration information was disclosed to law enforcement officials. ${ }^{106}$ This limitation on the use of the information to discover and prosecute future crimes, combined with the statute's prohibition of use regarding past and present crimes, meant that Freed and Sutherland were "not confronted by "substantial and "real", but merely "trifling or imaginary, hazards of incrimination.' "107

It is curious that, after emphasizing the protection against incrimination for future offenses provided by the administrative policy of nondisclosure, the Court added a paragraph suggesting that the fifth amendment required no such protection. Without further elaboration, Justice Douglas wrote: “Appellees' argument assumes the existence of a periphery of the SelfIncrimination Clause which protects a person against incrimination not only against past or present transgressions but which supplies insulation for a career of crime about to be launched. We cannot give the Self-Incrimination Clause such an expansive interpretation."108 The implication that the state can constitutionally compel self-incrimination regarding offenses not yet committed is inconsistent both with Marchetti and with the Freed Court's own reliance on the administrative policy of nondisclosure.

The Freed decision's inconsistency on this point is unfortunate because it suggests that a subsequent administration could depart from the previous policy, by providing registration information to other law enforcement

104. 390 U.S. at 54. Regarding the federal wagering statute's propensity to compel selfincrimination as to past or present crimes, see $i d$. at $44-49$.

105. 401 U.S. at 605-07.

106. Specifically, the opinion noted: "[N]o information filed is as a matter of practice disclosed to any law enforcement authority, except as the fact of nonregistration may be necessary to an investigation or prosecution under the present Act." 401 U.S. at 604 (emphasis deleted). The Court apparently did not consider it significant that the government had not disclosed this policy to the public, see id. at 604, and that Freed and Sutherland therefore could have reasonably concluded that registration would have been incriminating.

107. 401 U.S. at 606 (quoting Marchetti, 390 U.S. at 53 (quoting Rogers v. United States, 340 U.S $367,374(1951)))$; of. infra text accompanying note 109 (Marchetti reached the opposite conclusion on the same argument).

108. Freed, 401 U.S. at 606-07. In his separate opinion in Freed, Justice Brennan interpreted the Court's statement in a unique fashion. Justice Brennan joined the self-incrimination portion of the Court's opinion with the understanding that the statutory limit on prosecutorial use of registration information extended not only to past and present crimes, but also to future crimes of possession. "because possession is a continuing violation." Id. at 611 (Brennan. J., concurring in the judgment of reversal); see also id. n.2. With this caveat, Justice Brennan " agrec|d / with the Court that the SclfIncrimination Clause . . does not require that immunity be given as to the use of [registration] information in connection with crimes that the transfere might possibly commit in the future with the registered firearm." Id. at 611 . 
agencies, without reviving the fifth amendment concerns adjudicated in Haynes and Freed. The Court could have avoided creating this temptation, and could have placed a more effective limit on the discretionary authority of those controlling disclosure of the registration information, by unambiguously holding that the administrative policy of nondisclosure was necessary to save the statute from unconstitutionality. Reading a future crimes limitation into the 1968 Act in this fashion would have given permanence to a policy that otherwise is subject to the whims of its administrators. 109

The federal district court had accepted the other reason defendants advanced for dismissing the indictment: the failure to allege that the defendants knew the hand grenades were unregistered. The government argued on appeal that while the statute ${ }^{10}$ did require allegation and proof that the defendants knowingly possessed hand grenades, it did not require proof of knowledge (or any other mens rea) in regard to the unregistered status of the weapons. ${ }^{111}$ The Supreme Court accepted this reasoning in a strikingly overbroad embrace of strict liability.

After acknowledging that "mens rea was long a requirement of criminal responsibility," 112 Justice Douglas noted: "But the list of exceptions grew, especially in the expanding regulatory area involving activities affecting public health, safety, and welfare."113 Relying on two previous opinions upholding strict liability offenses under federal drug regulations, ${ }^{114}$ the Court concluded that the registration requirement under section 5861 was "a regulatory measure in the interest of public safety. . . . [H] and grenades . . . are highly dangerous offensive weapons, no less dangerous than .. narcotics ,"115

If the regulatory nature of section 5861 justified dispensing with the requirement of mens rea in regard to one element of the offense, however, it could justify applying strict liability to all the elements of the offense. Indeed, the drug regulation cases relied on by the Freed Court approved pure strict liability offenses, not just crimes with one or more strict liability elements. ${ }^{116}$ So the overbreadth of the Freed opinion invites prosecutors to apply section 5861 not only to persons who did not know of the unregistered status of the

109. Cf. infra text accompanying notes 201-05 (Freed was the basis for allowing truthful and immune testimony before a grand jury to be used to prove perjury, the one exception to the immunity, on the part of the defendant).

110. 26 U.S.C. $\$ 5861$ (d) (1982) ("It shall be unlawful for any person . . . to . . . possess a firearm which is not registered to him in the National Firearms Registration and Transfer Record . . . ."). A hand grenade is a "firearm" under 26 U.S.C. $\$ 5845$ (a), (f) (1982).

111. 401 U.S. at 612 (Brennan, J., concurring in the judgment of reversal).

112. Id. at 607 (citations omitted).

113. Id. (citing Morissette v. United States, 342 U.S. 246, 254 (1952)).

114. Id. at 609 (referring to United States v. Dotterweich, 320 U.S. 277 (1943), and United States v. Balint, 258 U.S. 250 (1922)).

115. 401 U.S. at 609 . Justice Douglas' uncritical acceptance ignores the overwhelmingly negative treatment strict liability has received from criminal law theorists. See, e.g., Hart, The tims of the Criminal Law. Law \& Contemp. Probs., Summer 1958, at 401, 419-25.

116. These drug regulation cases are cited supra, note 114. 
dangerous weapons they possessed, but also to those who did not even know that they were in possession of dangerous weapons. ${ }^{117}$

Justice Brennan recognized this defect in the Court's reasoning 18 and filed a separate opinion concurring in the result only. In his opinion, Justice Brennan began with the assertion that " [ $t]$ he existence of a mens rea is the rule of, rather than the exception to, the principles of Anglo-American criminal jurisprudence.' "119 Regarding the element of knowing possession of one of the weapons covered by section 5861 , he found little to rebut the application of this rule; ${ }^{20}$ concerning the unregistered status of the weapon, however, Justice Brennan discovered that "the case law under the provisions replaced by the current law dispensed with proof of intent in connection with this element."'121 This factor, plus the great "likelihood of governmental regulation" of weapons such as hand grenades, 122 convinced Justice Brennan that Congress did not intend to require proof of knowledge of the lack of registration in prosecutions under section 5861 .

Though the concurrence in Freed was more measured than the opinion of the Court, it too had faults. Justice Brennan did not offer sufficient reasons to overcome the presumption of a mens rea requirement. His reliance on the likelihood of regulation recalled the "regulatory offense" justification given by the Freed majority, a justification Justice Brennan himself criticized. ${ }^{123}$ In addition, the case law supporting the application of strict liability to the lackof-registration element was a very weak reed. Justice Brennan cited only Sipes v. United States, ${ }^{124}$ an opinion written by Justice Blackmun while he was a judge on the court of appeals. Sipes considered a prosecution for possession of a weapon made in violation of section 5861's predecessor statute; ${ }^{125}$ the weapon had been altered, which constituted the unlawful making. ${ }^{126}$ While the Sipes court held that knowledge of the alteration of the weapon was not

117. The language of 26 U.S.C. $\$ 5861$ (d) (1982), supra note 110 , would certainly permit this interpretation. See generally infra text accompanying notes 219-53. As to the possibility that one might innocently own a hand grenade without knowing it, see infra note 122 .

118. "It is no help in deciding what level of intent must be proved . . . to declare that the offense falls within the 'regulatory' category." 401 U.S. at $612-13$ (Brennan, J., concurring in the judgment of reversal). Many lower federal courts have implicitly agreed with this analysis by relying more on Justice Brennan's opinion in Freed than on the opinion of the Court. E.g., United States $\checkmark$. Renner, 496 F.2d 922, 926 (6th Cir. 1974).

119. 401 U.S. at 613 (Brennan, J., concurring in the judgment of reversal) (quoting Dennis v. United States, 341 U.S. 494, 500 (1951)).

120. Freed, 401 U.S. at 614 (Brennan, J., concurring in the judgment of reversal).

121. Id. at 616 (citing Sipes v. United States, 321 F.2d 174 (8th Cir.), cert. denied, 375 U.S. 913 (1963)); see infra text accompanying notes 124-28.

122. Freed, 401 U.S. at 616 (Brennan, J., concurring in the judgment of reversal). This assertion of the apparent likelihood of regulation fails to take account of the fact that there is a market for facsimile hand grenades, for use as paperweights and firecrackers. These uses clearly would not automatically alert one to the possibility of regulation. See TAsk Force, supra note 93, at 30-31.

123. See supra note 118.

124. 321 F.2d 174 (8th Cir.), cert. denied, 375 U.S. 913 (1963); see supra note 121.

125. The current provision appears at 26 U.S.C. $\$ 5861$ (c) (1982). For the prohibition contained in this provision, see supra text accompanying note 88 .

126. See 321 F.2d at 176. 
necessary for a conviction, ${ }^{127}$ the opinion also noted that Sipes himself had performed at least one of the alterations, which strongly implied that he knew of the unlawful making. ${ }^{28}$ Thus, the ruling used by the Freed concurrence to overcome the usual requirement of mens rea was unnecessary to support the holding in Sipes. Furthermore, it applied to a requirement of unlawful making, not to the element of lack of registration.

The Freed concurrence thus encourages prosecutors to speculate on how easy it might be to overcome the presumption of a mens rea requirement with regard to other elements of other offenses. ${ }^{129}$ A stricter adherence to mens rea requirements would thwart such prosecutorial creativity and the arbitrary exercise of discretion that can accompany it.

One further shortcoming of the Freed opinions is noteworthy. Neither Justice Douglas nor Justice Brennan considered the special mens rea problem raised by the conspiracy count against Freed and Sutherland. On one theory, conspiracy implies at least a knowledge requirement for all elements of the offense conspired to, even when no mens rea is required for some elements of the completed crime. ${ }^{130}$ Thus, even if knowledge of the unregistered status of the hand grenades would not be necessary under section 5861, that knowledge would be necessary to a prosecution for conspiracy to violate section 5861. No mention of this problem appeared in either of the Freed opinions. ${ }^{131}$

\section{B. Supreme Court Interpretation-United States v. Bass}

Eight months after United States $v$. Freed, the Court announced its decision in United States $v$. Bass, ${ }^{132}$ a prosecution under section 1202 of the appendix to title 18 of the United States Code. ${ }^{133}$ The government had charged Denneth Bass, a convicted felon, with illegal possession of two firearms. In the court of appeals, Bass won a reversal of his conviction because the prosecution had neither alleged nor proved that he had possessed the firearms "in commerce or affecting commerce." 134 On certiorari the Supreme Court's opinion turned on the proper construction of the language in section 1202 punishing "[a]ny person who . . . has been convicted . . . of a felony . . . who receives, possesses, or transports in commerce or affecting commerce ... any firearm."'135

127. Id. at 179.

128. Id. ("In any event, the inference that Sipes inserted the nail is proper and creates a knowing 'making' on his part.").

129. See infra text accompanying notes 207-18.

130. See W. LaFave \& A. Scott, Handbook on Criminal Law $\$ 61$, at 468 (1972) (citing United States v. Crimmins, 123 F.2d 271 (2d Cir. 1941) (Hand, J.)).

131. See infra note 253. The opinion of the Court did note that the facts in Freed satisfied conspiracy law's corrupt motive doctrine. 401 U.S. at 609 n.14. See generally W. LAFAve \& A. ScotT, supra note $130, \S 61$, at $468-70$.

132. 404 U.S. 336 (1971).

133. 18 U.S.C. app. \& 1202 (1982). For the prohibition in this section, see supra text accompanying notes $80-81$.

134. 434 F.2d 1296 (2d Cir. 1970), affd, 404 U.S. 336 (1971).

135. 18 U.S.C. app. § 1202 (a) (1982). 
The government argued-and two justices agreed ${ }^{136}$ - that the phrase "in commerce or affecting commerce" modified only the verb "transports" and therefore was inapplicable to a prosecution for possession under section 1202.137 Most of the lower federal courts that had faced the issue had accepted this argument. ${ }^{138}$

But a majority of the Court balked, on the ground that Congress' intent was unclear as to whether the phrase modified "possesses." Holding that "the statutory materials [we]re inconclusive," and that the Court was "left with an ambiguous statute,"139 the majority, speaking through Justice Marshall, elected to construe section 1202 in favor of the defendant. In support of this choice, the Bass Court strongly relied on the rule of strict construction of penal statutes: "[A]mbiguity concerning the ambit of criminal statutes should be resolved in favor of lenity." 140 The Court emphasized that such a rule would provide fair notice to those subject to the criminal laws, while maintaining a separation of powers between the legislature and the judiciary. ${ }^{141}$

Marshall also cited federalism as a reason for strictly construing the statute: "[T]he broad construction urged by the Government renders traditionally local criminal conduct a matter for federal enforcement."'142 Without a stronger indication from Congress, the Court refused to assume such a significant shift in the federal-state balance.

The Court's concern over federalism masked a deeper constitutional issue. Throughout his prosecution, Bass had argued that the statute as interpreted by the government was beyond the power of Congress to enact: No grant of constitutional authority contemplated federal intrusion into an area of purely local interest. ${ }^{143}$ Thus, according to Bass, application of the commerce nexus to possession, bringing it within the scope of the commerce clause, was necessary to save the provision from unconstitutionality. ${ }^{144}$

In reversing Bass' conviction, the Second Circuit had accepted much of this argument; the court expressed "serious doubt" about the constitutionality of the government's interpretation of section 1202.145 The Second Circuit had not had the benefit, however, of Perez $v$. United States, ${ }^{146} \mathrm{a}$

136. 404 U.S. at 356 (Blackmun, J., and Burger, C.J., dissenting).

137. See id. at 352-56 (Blackmun, J., and Burger, C.J., dissenting) (relying on congressional findings, legislative history, and statutory punctuation).

138. See id. at 351-52 \& n.I (Blackmun, J., and Burger, C.J., dissenting).

139. Id. at 347; see id. at 339-47 \& n.11 (finding grammar, punctuation, and legislative history equivocal).

140. Id. at 347 (quoting Rewis v. United States, 401 U.S. 808, 812 (1971)). See generally supra text accompanying note 59 .

141. 404 U.S. at 348. See generally supra note 25 and text accompanying note 27. Regarding the

Court's failure to mention the problem of arbitrary enforcement, see supra note 41 .

142. 404 U.S. at 350.

143. See id. at 338 .

144. See United States v. Bass, 434 F.2d 1296, 1297 (2d Cir. 1970), affd, 404 U.S. 336 (1971).

145. 434 F.2d at 1299 .

146. 402 U.S. 146 (1971). See generally Stern, The Commerce Clause Revisited-The Federalization of Intrastate Crime, 15 ARIz. L. REv. 271 (1973). 
Supreme Court opinion rendered after the circuit court's decision in Bass but before the high court's action in that case.

Perez upheld a federal anti-loansharking statute that required no proof of a commerce nexus, relying instead on congressional findings that all loansharking activity has an impact on interstate commerce. ${ }^{147}$ Because the Gun Control Act of 1968 contained a finding that a felon's possession of a firearm burdens interstate commerce, ${ }^{148}$ Perez would seem to dispel most doubts about the authority of Congress to criminalize such possession even in the absence of a commerce nexus. ${ }^{149}$

The Supreme Court's willingness to construe strictly the provision at issue in Bass, although its then recent decision in Perez would apparently have allowed a broader construction, is admirable. While construing the statute as the government urged would not directly have threatened constitutional rights, these rights ${ }^{150}$ were indirectly jeopardized: A contrary decision in Bass would have encouraged prosecutors to seek to avoid proving a commerce nexus in other federal criminal statutes, even those with congressional findings of impact on interstate commerce less explicit than those in Perez and Bass. ${ }^{151}$ As a result, defendants whose alleged acts should not have been the subject of a federal prosecution would have been haled into federal court. This development would have been pernicious, even if the same acts would have justified a state prosecution, ${ }^{152}$ because of the potential for harassment created by the prospect of multiple trials and multiple punishments. ${ }^{153}$

After adhering to the principles of strict construction so carefully, the Court surprisingly veered from them in the last paragraph of its opinion.

147. 402 U.S. at $154-57$.

148. 18 U.S.C. app. $\$ 1201(1)$ (1982).

149. See Stern, supra note 146, at 283. But see United States v. Bass, 434 F.2d 1296, 1300 (2d Cir. 1970) (distinguishing lower court decision in Perez because of different natures of congressional findings), aff $d, 404$ U.S. 336 (1971).

150. While commerce clause questions are typically stated in terms of the rights of the federal and state governments, also at issue in criminal cases involving the commerce clause is the defendant's right not to be subject to federal criminal jurisdiction for acts that do not fall within the legislative authority of the federal government. See generally L. Tribe, American Constitutional LAw $\S 5-21$ to -22 (1978). In his treatise, Tribe argued that the Supreme Court should "treat states' rights largely as mirror images of individual rights," id. $\$ 5-21$, at 307 , and analyzed National League of Cities v. Usery, 426 U.S. 833 (1976) (overruled by Garcia v. San Antonio Metropolitan Transit Auth., $105 \mathrm{~S}$. Ct. 1005 (1985)) (voiding, on commerce clause grounds, application of minimum wage and maximum hour provisions to state and local governments), as a reflection of "the existence of protected expectations-of rights-to basic government services." L. TRIBE, supra, § 5-22, at 313 . In a criminal case, the commerce clause guarantees the defendant's right to a decentralized decisionmaking process, with its promises of "greater accuracy" and of "greater protection of liberty." Id. $\$ 5-21$, at 307 (emphasis deleted). On the relationship between protected rights and strict construction, see supra text accompanying notes 49-53.

151. Cf. infra text accompanying notes 254-98 (other courts' reliance on Bass).

152. See P. Low, J. Jefrries \& R. Bonnie, supra note 22, at 112 (possibility of state prosecution lessens fair notice rationale for strict construction in Bass).

153. See generally Abbate v. United States, 359 U.S. 187 (1959) (after defendants were convicted in state court on state grounds, their prosecution in federal court on federal grounds was not barred by the double jeopardy clause of the fifth amendment); Bartkus v. Illinois, 359 U.S. 121 (1959) (due process was not violated by the petitioner's state prosecution after acquittal for a federal offense based on substantially the same evidence). 
Although the extent of the required nexus to commerce had not previously been an issue in Bass, ${ }^{154}$ Justice Marshall suggested some ways in which the government might prove possession in or affecting commerce. ${ }^{155}$ Providing such dicta to guide lower courts is not unreasonable per se. The Court went on, however, to specify a means of showing receipt in or affecting commerce, a provision of section 1202 that Bass had never been charged with violating. According to Bass, the commerce nexus requires only "that the firearm received has previously traveled in interstate commerce."156 In short, a defendant might be convicted although the gun's only travel in interstate commerce occurred long before his receipt of it. The Court added, with apparent pride, "This is not the narrowest possible reading of the statute ... ."157

Unwilling to seem "soft" on firearms, the Court alerted prosecutors to the usefulness of section 1202's receipt provision in a case like Bass: One who possesses must have received, leaving the prosecution only the burden of tracing the firearm's movement across state lines. To decide such a matter without the aid of specific facts and focused advocacy reflects poor judicial craftsmanship. To decide the issue by construing the commerce nexus in the broadest possible way is doubly distressing, for it maximizes the possibility of prosecutorial abuse. ${ }^{158}$

\section{Supreme Court Interpretation-United States v. Biswell}

A third case arising from the Gun Control Act of 1968 reached the Court five months after United States v. Bass. In United States $v$. Biswell, ${ }^{159}$ the government prosecuted Loran Biswell, a pawnbroker licensed to sell only sporting weapons, for possessing sawed-off rifles. ${ }^{160}$ Federal agents discovered the firearms while searching Biswell's pawnshop pursuant to section 923 of title 18, which authorizes federal law enforcement officers to "enter during business hours the premises (including places of storage) of any firearms or ammunition ... dealer ... for the purpose of inspecting or examining . . a any firearms or ammunition kept or stored by such ... dealer."161 The agents had no warrant; Biswell allowed them to enter the storeroom where the unlicensed weapons were found only after the agents

154. See 404 U.S. at 351. (Brennan, J., concurring in the judgment). Justice Brennan refused to join that portion of the Court's opinion commenting on the evidence necessary to prove a nexus to commerce.

155. " [A] person 'possesses . . . in commerce or affecting commerce' if at the time of the offense the gun was moving interstate or on an interstate facility, or if the possession affects commerce." 404 U.S. at 350 .

156. Id.

157. Id. at 350-51

158. See infra text accompanying notes 299-307.

159. 406 U.S. 311 (1972).

160. The indictment alleged a violation of 26 U.S.C. $\$ 5801$ (1982). The sawed-off rifles were "firearms" under 26 U.S.C. $\$ 5845$ (1982), and a dealer in such firearms is required to pay a special occupation tax of $\$ 200$ each year under 26 U.S.C. $\$ 5801$ (1982). Sep Bisuell. 406 U.S. at 313 n.2.

161. 18 U.S.C. $\$ 923(\mathrm{~g})$ (1976); see supra text accompanying note 77. 
had asserted that section 923 justified their search of the storeroom without a warrant. ${ }^{162}$

At trial and on appeal, Biswell questioned the propriety of the search under section 923 and also challenged the constitutionality of that section under the fourth amendment, which bars unreasonable searches and seizures. See v. City of Seattle ${ }^{163}$ had held that "administrative entry, without consent, upon the portions of commercial premises which are not open to the public may only be compelled through prosecution or physical force within the framework of a warrant procedure." 164 Unless it fell within some exception to See's warrant requirement, section 923 was plainly unconstitutional.

In response to Biswell's argument, the government relied on the exception to See recognized in 1970 in Colonnade Catering Corp. v. United States. ${ }^{165}$ In that case the Court upheld Congress' power to authorize warrantless administrative searches of retail liquor dealerships, because of "the long history of the regulation of the liquor industry." 166 In Biswell, the government argued that the firearms industry is as heavily regulated as the liquor industry and therefore that Congress should have a similar power to authorize warrantless searches of gun dealerships.

The Court, in an opinion by Justice White, agreed. ${ }^{167}$ While acknowledging that "[f]ederal regulation of the interstate traffic in firearms is not as deeply rooted in history as is governmental control of the liquor industry," Justice White noted that "[l]arge interests are at stake," 168 including the prevention of violent crime. Because "regulatory inspections further urgent federal interest," 169 the Court upheld the constitutionality of section 923.

Justice Douglas, the author of Colonnade, dissented in Biswell, in part because "Colonnade ... rested heavily on the unique historical origins of government regulation of liquor,"170 origins that predated the adoption of the fourth amendment. ${ }^{171}$ Justice Douglas' dissent implied that only a

162. 406 U.S. at 312.

163. 387 U.S. 541 (1967).

164. Id. at 545; see also Camara v. Municipal Court, 387 U.S. 523 (1967) (similar holding for gdministrative entry of residences).

165. 397 U.S. 72 (1970).

166. Id. at 75 .

167. Biswell, 406 U.S. at 315-16.

168. Id. at 315.

169. Id. at 317. The Court also contended that with warrantless searches of gun dealerships, "the possibilities of abuse and the threat to privacy are not of impressive dimensions," $i d$,, because " $|\mathrm{w}| \mathrm{h}$ en a dealer chooses to engage in this pervasively regulated business . . ., he does so with the knowledge that his business [premises] . . will be subject to effective inspection." Id. at 316 . Such an assumption might be proper as to liquor retailers and wholesalers, but its application to the much smaller and less lucrative business of gun licensees is more dubious. Most firearms licensees deal 'only on a part-time basis, from their homes. See S. Brill., Firearms Abuse 80 (1977).

170. Biswell, 406 U.S. at 318 (Douglas, J., dissenting).

171. Colonnade, 397 U.S. at 75 (citing inspection statutes from 17th-century England and Massachusetts and a federal inspection statute enacted in 1791, the year of the fourth amendment's adoption). 
centuries-long history of regulation would justify exception from the warrant requirement set out in See. ${ }^{172}$

Biswell thus joined Freed and Bass in a mixed bag of early constructions of the Gun Control Act of 1968. In 1971 and 1972, the Court sometimes concerned itself with problems of arbitrary enforcement and sometimes did not. Enforcement practices were directly at issue in Freed and Biswell; in the former case, the Court took a somewhat ambiguous stand in favor of restricting law enforcement access to registration information, while in Biswell the majority granted agents broad power to conduct warrantless searches. With respect to construction of the elements of criminal offenses, which has an indirect but crucial impact on law enforcement, Freed adopted an extremely liberal stance toward mens rea requirements, while Bass embraced strict construction of one provision's act requirement. Even Bass, though, equivocated in its commitment to strict construction.

IV

The Perils of Failing to Follow Strict Construction Principles

Surveying the defendants in United States $v$. Freed, United States $v$. Bass, and United States $v$. Biswell, one is tempted to say that they amply merited punishment. If the government's allegations were true, Freed and Sutherland possessed highly dangerous explosive devices without authorization; 173 in the trials of Bass and Biswell, the prosecution had proved that Bass was a convicted felon in possession of firearms ${ }^{174}$ and that Biswell was a firearms dealer holding gangster-style weapons that he had no right to possess. ${ }^{175}$ Each defendant thus threatened significant wrongdoing. How can it be argued that a court should have foregone punishing each of them?

Such an argument begins by focusing not on the individuals Freed and Sutherland, Bass, and Biswell, but on the impact of those decisions on subsequent cases. The Court's willingness in Biswell to stretch the fourth amendment ${ }^{176}$ created an incentive for law enforcement officials to seek further elasticity in that amendment's protection. In addition, the Court's failure in Freed to enunciate clearly its adherence to fifth amendment principles $^{177}$ opened the way for some erosion of those principles.

172. This implication is undercut by Justice Douglas's own words in Colonnade, that "the problems of 'licensing programs' requiring inspection . . . can be resolved 'on a case-by-case basis under the general Fourth Amendment standard of reasonableness." "397 U.S. at 77 (quoting See, 387 U.S. at 546). But Colonnade had, in turn, misapplied the See language, which had envisioned a pure reasonableness analysis only in regard to "licensing programs which require inspections prior 10 operating a business or marketing a product," See, 387 U.S. at 546 (emphasis added), something quitc different from the ongoing inspections contemplated by the statutes at issue in Colommade and Biswell.

173. See supra text accompanying notes 95-96.

174. See supra text accompanying note 134 .

175. See supra text accompanying note 160 .

176. See supra text accompanying notes 167-69.

177. See supro text accompanying notc 108. 
Similarly, the Court's refusal to construe strictly the mens rea requirement in Freed ${ }^{178}$ led to a number of convictions of defendants with claims far more meritorious than Freed's and Sutherland's. Although the Bass Court's strict construction of an act requirement in the 1968 Act produced many favorable results, its dictum regarding receipt in commerce ${ }^{179}$ made possible the subsequent dilution of the Bass holding. Thus, Freed, Bass, and Biswell saw the Court fail to apply adequate controls to the exercise of law enforcement authority.

\section{A. Costs of Extending Warrantless Searches and Compulsory Self-Incrimination}

Federal law enforcement officers at both the police and prosecutorial levels have seized upon United States $v$. Biswell to create a massive and everexpanding loophole in the fourth amendment's prohibition of warrantless searches. In the Supreme Court alone, prosecutors attempted to use Biswell to justify warrantless border searches, ${ }^{180}$ tax seizures, ${ }^{181}$ searches of international mail, ${ }^{182}$ occupational safety and health inspections, ${ }^{183}$ random automobile stops, ${ }^{184}$ and mine safety inspections. ${ }^{185}$

The argument succeeded only with regard to searches of international mail ${ }^{186}$ and mine safety inspections. ${ }^{187}$ Prosecutors were far more successful in the circuit courts, however. These courts used the Biswell rationale in upholding warrantless agricultural inspections at airports; ${ }^{188}$ searches of motor vehicle inspection stations; ${ }^{189}$ searches of parolees; ${ }^{190}$ inspections of

178. See supra text accompanying notes $112-15$.

179. See supra text accompanying notes 154-57.

180. Almeida-Sanchez v. United States, 413 U.S. 266 (1973).

181. G.M. Leasing Corp. v. United States, 429 U.S. 338 (1977).

182. United States v. Ramsey, 431 U.S. 606 (1977).

183. Marshall v. Barlow's, Inc., 436 U.S. 307 (1978).

184. Delaware v. Prouse, 440 U.S. 648 (1979)

185. Donovan v. Dewey, 452 U.S. 594 (1981).

186. In United States v. Ramsey, 431 U.S. 606, 620-22 (1977), the Court implied that the diminished expectation of privacy of one who sends mail across an international border is similar to the diminished privacy expectation of one who enters the weapons trade. Cf. supra note 169.

187. Donovan v. Dewey, 452 U.S. 594, 602 (1981), found "a substantial federal interest in improving the health and safety conditions in the Nation's underground and surface mines." Further, "[t]he Act is specifically tailored to address th[at] concern, and the regulation of mines it imposes is sufficiently pervasive and defined that the owner of such a facility cannot help but be aware that he "will be subject to effective inspection." 'Id. at 603 (quoting Bistuell, 406 U.S. at 316 ). Cf. supra text accompanying notes 167-69.

In response to Dewey's argument that there was no long history of regulation of stone quarries, 452 U.S. at 605, the Court noted that while "the duration of a particular regulatory scheme will often be an important factor in determining" the applicability of the warrant requirement, it could not be "the only criterion." Id. at 606 (citing Bisuell. 406 U.S. at 315); of. supra text accompanying notes $170-72$.

188. United States v. Schafer, 461 F.2d 856 (9th Cir. 1972).

189. United States v. Genareo, 467 F.2d 476 (3d Cir. 1972).

190. Iatta v. Fitzharris, 521 F.2d 246 (9th Cir. 1975) (en banc); $c$. United States v. ConsueloGonzalez, 521 F.2d 259 (9th Cir. 1975) (en banc) (search of probationer). But spe United States v. Bradley, 571 F.2d 787 (4th Cir. 1978); of. United States v. Workman, 585 F.2d 1205 (4th Cir. 1978) (search of probationer). 
construction sites, ${ }^{191}$ massage parlors, ${ }^{192}$ drug manufacturers, ${ }^{193}$ insurance companies, ${ }^{194}$ and pharmacies; ${ }^{195}$ affirmative action compliance checks;196 perishable commodities inspections; ${ }^{197}$ and searches by the Coast Guard and the National Marine Fisheries Service. ${ }^{198}$ It is certainly arguable that these courts of appeals decisions have extended Biswell further than the 1972 Court would have gone-indeed, further even than the current Supreme Court would go if it were to review each of them. Thus, one cost of judicial decisions granting law enforcement officers leeway is the clear likelihood that other courts will extend that precedent, allowing even greater leeway.

Other costs result even when a subsequent court resists the temptation to expand the precedent. By the time a later court has refused to extend a precedent like Biswell, there usually will have been a warrantless search and a prosecution based on that search. These actions will have compromised the defendant's life in a way that no judicial victory can cure. Even more costly is the breach of wholly innocent persons' privacy rights : For every illegal search that turns up an offense, there will be scores, even hundreds, of warrantless searches which reveal no criminal activity. ${ }^{199}$ For the innocent, there will be neither judicial vindication nor redress of any kind. ${ }^{200}$ In order to avoid these costs, courts should refrain from giving law enforcement officials the incentive to test the limits of their powers to search and seize. Reaching a different result in Biswell would have been a step in the direction of reducing this incentive.

Similar problems arose, but to a lesser extent, in the wake of the Freed Court's fifth amendment holding. By implying that the fifth amendment

191. Frey v. Panza, 621 F.2d 596 (3d Cir. 1980).

192. See Oster v. New Orleans, 631 F.2d 71 (5th Cir. 1980); Pollard v. Cockrell, 578 F.2d 1002 (5th Cir. 1978). In Pollard, the court wrote concerning massage parlors:

It is a business which is being inspected and one which has a history of regulation, albeit not as extensive as the liquor or firearms industries, and as a member of a regulated business, a licensee does impliedly consent to inspections at any and all reasonable times and places by obtaining a license... .

Id. at 1014 (citations omitted) (quoting City of Indianapolis v. Wright, 267 Ind. 471, 479, 371 N.E.2d 1298,1302 (1978)); cf. supra note 169 .

193. United States v. Jamieson-McKames Pharmaceuticals, Inc., 651 F.2d 532 (8th Cir. 1981). But see United States v. One Device, More or Less, Labeled in Part: "Theramatic," 641 F.2d 1289 (9th Cir. 1981).

194. United States v. Gordon, 655 F.2d 478 (2d Cir. 1981). But cf. CAB v. United Airlines. Inc., 542 F.2d 394 ( 7 th Cir. 1976) (inspection of airline records by regulator).

195. United States v. Acklen, 690 F.2d 70 (6th Cir. 1982); In re Searches and Scizures Conducted on October 2-3, 1980, 655 F.2d 775 (7th Cir. 1981); United States v. Schiffman, 572 F.2d 1137 (5th Cir. 1978); United States ex rel. Terraciano v. Montayne, 493 F.2d 682 (2d Cir. 1974).

196. First Alabama Bank v. Donovan, 692 F.2d 714 (1 l th Cir. 1982); United States v. Mississippi Power \& Lighı Co., 638 F.2d 899 (5/h Cir. 1981); United States v. New Orleans Pub. Serv., Inc., 553 F.2d 459 (5th Cir. 1977), vacated on olher grounds, 436 U.S. 942 (1978).

197. Wayne Cusimano, Inc. v. Block, 692 F.2d 1025 (5th Cir. 1982).

198. United States v. Kaivo Maru No. 53, 699 F.2d 989 (9th Cir. 1983); United States v. Raub. 637 F.2d 1205 (9th Cir. 1980); United States v. Arra, 630 F.2d 836 (1st Cir. 1980); United States v. Hilton, 619 F.2d 127 (1st Cir. 1980). But see United States v. Piner, 608 F.2d 358 (9th Cir. 1979). 199. See Hardy \& Chotiner, supra note 9, at 196.

200. The searches having been made in good faith reliance on Bisaell, no damages are recoverable. See generally Pierson v. Ray, 386 U.S. 547 (1967). 
offered no protection against self-incrimination regarding future crimes, Freed opened the door for decisions like United States v. Apfelbaum. ${ }^{201}$ The government had compelled Apfelbaum's testimony before a grand jury under a grant of immunity that prohibited subsequent use against him of the compelled testimony. The single exception to the immunity agreement was that false statements to the grand jury could form the basis of a perjury charge. ${ }^{202}$ When the government later charged Apfelbaum with perjury, it introduced not only the allegedly false compelled testimony, but also the testimony leading up to the false statements; the government conceded that this other testimony by Apfelbaum was truthful. Apfelbaum argued that his truthful compelled statements should be inadmissible. If they were admitted into evidence, he reasoned, the government would have succeeded in compelling him to incriminate himself with regard to a future crime of perjury. In other words, the government would have forced Apfelbaum to give answers that would help to convict him of the perjury he was about to commit. The Court rejected this contention, holding that "a future intention to commit perjury . . . is not by itself sufficient to create a 'substantial and "real" hazard that permits invocation of the Fifth Amendment." 203 In support of this conclusion the Court quoted in full Freed's enigmatic rejection of the fifth amendment as "insulation for a career of crime about to be launched."'204

If Freed had not cast doubt on the fifth amendment's prevention of compulsory self-incrimination regarding future crimes, it is questionable whether the Apfelbaum prosecutor would have been tempted to use the truthful portion of Apfelbaum's compelled testimony. Moreover, if he had not been so tempted, there would have been no Apfelbaum decision-which decision will in turn encourage prosecutors to seek further diminutions of the fifth amendment's protections. ${ }^{205}$

\section{B. Loosened Mens Rea Requirements After United States v. Freed}

In considering the fourth and fifth amendments, the Court that decided United States $v$. Biswell and United States $v$. Freed most likely was aware that its rulings would have direct impacts on law enforcement. In considering the substantive questions of mens rea in Freed and actus reus in United States $v$. Bass, the Court should have been aware of the law enforcement implications

\footnotetext{
201. 445 U.S. 115 (1980).

202. See United States v. Wong, 431 U.S. 174 (1977).

203. Apfelbaum, 445 U.S. at 131 (quoting Marchetti v. United States, 390 U.S. 39, 53 (1968)).

204. Apfelbaum, 445 U.S. at 129-30 (quoting Freed, 401 U.S. 601, 606-07; see supra text accompanying note 108). The Apfelbaum Court also quoted a portion of the Freed concurrence in which Justice Brennan agreed with this aspect of the majority opinion. .tpfelbaum, 445 U.S. at 130 (quoting Freed, 401 U.S. at 611 (Brennan, J., concurring in the judgment of reversal)); see supra note 108.

205. Both of the Apfelbaum concurrences expressed concern about the extension of the Court's holding to trials for perjury during noncompelled testimony; the majority opinion suggested that truthful statements in previous compelled testimony would also be admissible in such trials. See At) felbaum, 445 U.S. at 133 (Brennan, J., concurring in the judgment); id. (Blackmun, J., and Marshall. $\mathrm{J}$., concurring in the judgment).
} 
of its decisions. The substantive holding in Freed demonstrates that the Court either was not aware of these implications or had no interest in limiting overzealous law enforcement.

The Court's approval in Freed of strict liability under the Gun Control Act of 1968 sparked two prosecutorial campaigns: to import the Freed holding into other areas of criminal law ${ }^{206}$ and to extend Freed to other aspects of the 1968 Act. The Supreme Court adopted the Freed analogy in a case involving the shipment of corrosive liquid without proper papers ${ }^{207}$ but rejected it in a price-fixing prosecution. ${ }^{208}$ In the courts of appeals, Freed eased the adoption of strict liability in trials involving drugs, ${ }^{209}$ gambling devices, ${ }^{210}$ weapons concealed on airline passengers, ${ }^{211}$ fishing in the contiguous zone, ${ }^{212}$ wholesale transactions with retail liquor dealers, ${ }^{213}$ failure to withhold income $\operatorname{tax},{ }^{214}$ and trespass on a military reservation. ${ }^{215}$ The Freed analogy was rejected in prosecutions for failure to notify one's draft board of a change in status, ${ }^{216}$ failure to report currency transactions, ${ }^{217}$ and reentry by a deported alien. ${ }^{218}$ Even in those cases that refused to adopt strict liability, harm was done to the defendants, in the form of public accusations and public trials. In at least some of the cases analogized to Freed, further damage was done because the courts imposed liability without fault where the Freed Court probably would not have done so.

The latter point emerges more clearly from examination of cases applying Freed to other crimes under the 1968 Act. In United States $v$. Gross, 219 a prosecution under section 922 of title 18, the government accused Gross of dealing in firearms without a license. ${ }^{220}$ The undisputed facts were that

206. Cf. supra text accompanying notes 180-98 (lower federal courts' extension of Biswell to other factual situations).

207. United States v. International Minerals \& Chem. Corp., 402 U.S. 558 (1971). The Court noted that:

[W] here, as here and as in . . Freed, dangerous or deleterious devices or products or obnoxious waste materials are involved, the probability of regulation is so great that anyone who is aware that he is in possession of them or dealing with them must be presumed to be aware of the regulation. Id. at 565 .

208. United States v. United States Gypsum Co., 438 U.S. 422 (1978).

209. United States v. Hillman, 461 F.2d 1081 (9th Cir. 1972). But $c$. Lennon v. INS, 527 F.2d 187

(2d Cir. 1975) (evaluating strict liability drug offense in deportation proceeding).

210. United States v. Various Gambling Devices, 478 F.2d 1194 (5th Cir. 1973).

211. United States v. Flum, 518 F.2d 39 (8th Cir. 1975); United States v. Margraf, 483 F.2d 708 (3d Cir.), vacated on other grounds, 414 U.S. 1106 (1973). But see United States v. Lee, 539 F.2d 606 (6th Cir. 1976).

212. United States v. Ayo-Gonzalez, 536 F.2d 652 (5th Cir. 1976).

213. United States v. Campbell, 542 F.2d 548 (10th Cir. 1976).

214. United States v. Erne, 576 F.2d 212 (9th Cir. 1978).

215. United States v. Mowat, 582 F.2d 1194 (9th Cir.), cert. denied, 439 U.S. 967 (1978).

216. United States v. Figurell, 462 F.2d 1080 (3d Cir. 1972).

217. United States v. Warren, 612 F.2d 887 (5th Cir. 1980) (en banc).

218. United States v. Anton, 683 F.2d 1011 ( 7 th Cir. 1982). For other cases refusing to imposc strict liability, see supra notes $209,211$.

219. 451 F.2d 1355 (7th Cir. 1971).

220. The law provides that it is unlawful "for any person, except a licensed importer, licensed manufacturer, or licensed dealer, to engage in the business of . . dealing in fircarms or ammunition, or in the course of such business to ship, transport, or receive any firearm or 
Gross, who managed the sporting goods department of a K-Mart, personally bought used guns from store customers and then resold the guns thus acquired. ${ }^{221}$ He argued that this behavior did not constitute dealing and, even if it did, that he had no intent to engage in dealing; ${ }^{222}$ the intent argument relied in part on Gross' interpretation of an Internal Revenue Service booklet that indicated that an unlicensed individual could sell a firearm to another person who resided in the same state as the seller. ${ }^{223}$

The Seventh Circuit Court of Appeals found that Gross' conduct constituted dealing and that section 922 did not require any proof of an intent to deal in firearms. For the latter point, the court relied on Freed. ${ }^{224}$ While it may have been easy to presume that possessors of hand grenades knew they were engaged in wrongdoing (and thus easy to dispense with mens rea), it should have been far more difficult to assume that Gross, who bought and sold a few guns in allegedly mistaken reliance on a government document, ${ }^{225}$ acted with culpable intent. Nevertheless, the court affirmed his conviction.

A more widespread injustice flowing from the Freed decision concerns defendants charged under section 5861 of the Internal Revenue Code with possession of gangster-style weapons such as submachine guns and fully automatic rifles. ${ }^{226}$ The difficulty here is that these weapons may be externally indistinguishable from legal weapons, all modifications having been done internally. With but one exception, ${ }^{227}$ the courts of appeals have held that the government must prove only that the defendant knew he possessed a firearm-not that the defendant knew of the characteristics that made the firearm illegal under the statute. ${ }^{228}$ The decisions relied on Freed.

For example, in United States v. Thomas ${ }^{229}$ the defendant claimed (without contradiction) that he had found a firearm some sixteen and one-half inches long while horseback riding. Thinking it was an antique pistol, Thomas kept

ammunition in interstate or foreign commerce." 18 U.S.C. $\S 922(a)(1)$ (1982); see supra text accompanying note 67 .

221. Gross, $451 \mathrm{~F} .2 \mathrm{~d}$ at 1356 . The store did not accept guns as trade-ins. Id.

222. Id. at $1357-58,1360$.

223. Id. at 1358; see also United States v. Turcotte, 558 F.2d 893 (8th Cir. 1977) (rejecting, on authority of Freed, mistake-of-law argument regarding convicted felon's right to purchase firearms): United States v. Powell, 513 F.2d 1249 (8th Cir. 1975) (rejecting, on authority of Frped, reliance on advice of counsel regarding convicted felon's right to purchase firearms).

224. Cross, 451 F.2d at 1360.

225. See generally Cox v. Louisiana, 379 U.S. 559 (1965); Ralev v. Ohio, 360 U.S. 423 (1959). Gross's "clean hands" were subject to question. See Gross, 451 F.2d at 1357, 1358 \& n.4. Nevertheless, the jury, properly instructed on a mens rea requirement, would have been the appropriate body for resolving the issue.

226. See supra text accompanying notes 83-92.

227. United States v. Herbert, 698 F.2d 981, 986 (9th Cir. 1983) ("In this case, the firearms involved were weapons that had been only internally modified, and from the exterior looked like perfectly legal semi-automatic pistols.").

228. United States v. McCauley, 601 F.2d 336 (8th Cir. 1979); Morgan v. United States. $56+$ F.2d 803 (8th Cir. 1977); United States v. Thomas, 531 F.2d 419 (9th Cir.), cor. denied. 425 U.S. 995 (1976); United States v. Cowper, 503 F.2d 130 (6th Cir. 1974); United States v. DeBartolo. 482 F.2d 312 (1st Cir. 1973); United States v. Vasquez, 476 F.2d 730 (5th Cir. 1973).

229. 531 F.2d 419 (9th Cir.), cert. denied, 425 U.S. 995 (1976). 
it as a souvenir and later pawned it. ${ }^{230}$ The weapon was in fact a .22 caliber rifle with a short barrel; section 5861 of the Internal Revenue Code requires the registration of such a weapon prior to its possession and the payment of a tax prior to its transfer. ${ }^{231}$

In his prosecution for violating section 5861, Thomas argued that his mistake regarding the nature of the firearm should be a defense, but the trial court specifically rejected this contention. ${ }^{232}$ On appeal, the Ninth Circuit affirmed, holding that the government needed to prove only that the defendant knew he possessed and transferred a firearm. ${ }^{233}$ The decision extensively quoted opinions of the Supreme Court ${ }^{234}$ and the First Circuit Court of Appeals. ${ }^{235}$ Both of the quoted decisions derived major support from Freed. ${ }^{236}$

The inequity of the Thomas decision was emphasized in Judge Hufstedler's dissent, which argued that inferring knowledge of wrongdoing from possession of a firearm is not the same thing as inferring such knowledge from possession of hand grenades. ${ }^{237}$ The prevalence of ordinary firearms in our society means that a person in Thomas' position is given no reason to suspect that his conduct is criminal.238 Consequently, Judge Hufstedler concluded, the government should at least be required to prove that Thomas knew he possessed and transferred a short-barreled rifle. ${ }^{239}$ The Thomas dissent correctly analyzes the specific mens rea question involved, but the issue never would have arisen if Freed had been decided differently: Without the Freed Court's embrace of strict liability, it is unlikely that a federal prosecutor would have been inclined to charge Thomas in the first place.

230. 531 F.2d at 420.

231. 26 U.S.C. $\$ 5861$ (d)-(e) (1982); see supra text accompanying notes 88-89. Because this section would also render guilty the pawnbroker who accepted the weapon, it is likely that he too mistook the rifle for an antique pistol.

232. Thomas, 531 F.2d at 420. A question propounded by the jury during its deliberations suggested that the jurors believed Thomas's version of the facts. Id.

233. Id. at $421-22$.

234. Id. at $421 \&$ n.4 (quoting United States v. International Minerals \& Chem. Corp.. 402 U.S. 558, 564-65 (1971)); see supra note 207 and accompanying text.

235. Thomas, 531 F.2d at 421-22 (quoting United States v. DeBartolo, 482 F.2d 312, 316-17 (1st Cir. 1973)). The Thomas court did not quote the DeBartolo court's caveat: "We need not consider whether a mistaken belief that an object is, sav, an antique flintlock (thus perhaps a 'gun') would be a defense." 482 F.2d at 315 n.4.

236. See United States v. International Minerals \& Chem. Corp., 402 U.S. 558, 560, 564-65

(1971); United States v. DeBartolo, 482 F.2d 312, 315-17 (1st Cir. 1973).

237. Perhaps the halcyon day may come when Americans accept the idea that all guns are "highly dangerous offensive weapons, no less dangerous than . . narcotics." (United States :. Freed, 401 U.S. at 609) and when they "would hardly be surprised to learn that possession of [hand guns and rifles like possession of] hand grenades is not an innocent act." (Id.) That das has not arrived.

Thomas, 531 F.2d at 422-23 (Hufstedler, J., dissenting) (omissions and alterations in original).

238. Millions of Americans possess different varieties of hand guns and rifles without any consciousness of wrongdoing. . . . As desirable as mav be the contrary view, our societ does not put hand guns and rifles in the same category of suspected dangerousness as machine guns. hand grenades, sawed-off shotguns, and other lethal hardware.

Thomas, 531 F.2d at 423. The fact that the $1968 \mathrm{Act}$ excmpts antique weapons from its coverage reinforces this view. Sep 18 U.S.C. \$ 921(a)(3), (16) (1982).

239. Thomas, 531 F.2d at 423-24 (Hufstedler, J., dissenting). 
Another defect springs from the mens rea holding in Freed. In some prosecutions under section 922 of title 18 and under section 1202 of the appendix to title 18 , it is necessary to prove that the defendant has been convicted of a felony. ${ }^{240}$ Relying on Freed, the courts of appeals have held that a defendant's mistaken belief that he is not a convicted felon is no defense. ${ }^{241}$ In United States $v$. Sutton, ${ }^{242}$ for instance, the Seventh Circuit affirmed Sutton's conviction under section $1202^{243}$-even though the state that had convicted him of a felony had restored his civil rights and had issued him a permit authorizing him to possess firearms, a permit which was, under state law, available only to nonfelons. ${ }^{244}$

According to the appellate court, it was proper not to instruct the jury on the defendant's knowledge of his status as a convicted felon, because section 1202 “does not require such knowledge."245 A person without a previous felony conviction may legally purchase the guns that Sutton bought. To the extent Sutton believed he was such a person, ${ }^{246}$ he acted without mental fault. Nothing about his situation can be said to have put him on notice of his proximity to wrongdoing. The Freed analogy should therefore have failed on the Sutton facts.

A final example of the extreme prosecutions for which the strict liability holding in Freed is at least partially responsible is United States $v$. Parker. ${ }^{247}$ Parker shared a house with two others. When a visitor to the house became rowdy and cut Parker, he armed himself with a shotgun belonging to one of his roommates and fled the house. The defendant carried the gun, which was an unregistered sawed-off shotgun (and therefore illegal for anyone to possess, under section $\mathbf{5 8 6 1}$ of the Internal Revenue Code ${ }^{248}$ ), for approximately thirty minutes, apparently in order to defend himself if confronted by his previous attacker. ${ }^{249}$ At trial Parker argued that the

240. See supra text accompanying notes $62,74 \& 80$.

241. United States v. Allen, 699 F.2d 453 (9th Cir. 1982); United States v. Giles, 640 F.2d 621 (5th Cir. 1981); United States v. Pruner, 606 F.2d 871 (9th Cir. 1979); United States v. Goodie, 524 F.2d 515 (5th Cir. 1975); United States v. Sutton, 521 F.2d 1385 (7th Cir. 1975). But cf. United States v. Renner, 496 F.2d 922 (6th Cir. 1974) (government required to prove that defendant knew he had been indicted for felony).

242. 521 F.2d 1385 (7th Cir. 1975).

243. Section 1202 penalizes "[a]ny person who has been convicted by a court of the United States or of a State or any political subdivision thereof of a felony . . . and who receives, possesses, or transports in commerce or affecting commerce .. any firearm." 18 U.S.C. app. \$ 1202(a)(1) (1982); see supra text accompanying note 80.

244. Sutton, 521 F.2d at 1386-87. The restoration of rights was a discretionary act of the governor. Id. The permit, known as a Firearms Owner's Identification card, is available to any applicant, but the relevant statute specifically excludes those convicted of a felony. Il.L. ANN. STAT. ch. 38, \$ 83-4 (Smith-Hurd 1977) (amended 1984).

245. Sulton, 521 F.2d at 1391 (citing Freed, 401 U.S. at 609).

246. Although there was evidence that Sutton still considered himself a convicted felon, 521 F.2d at 1391, this should have been an issue for the jury, not the appellate court. See supra note 295. The jury's disposition of other charges against Sutton indicates that the jurors believed that he did not know himself to be a convicted felon. Sutton, 521 F.2d at 1386.

247. 566 F.2d 1304 (5th Cir. 1978).

248. See supra text accompanying note 89 .

249. Parker, 566 F.2d at 1305. 
government's burden of proving a knowing possession included proof of "possession not justified by some innocent reason." 250 Amazingly, the government's reply argued that under section 5861, "criminal liability . . . is absolute for those receiving or possessing illegal firearms regardless of how innocent or exigent the circumstances." 251 The Fifth Circuit all but adopted the government's position; the court stopped short only because the factsParker held the gun for a few minutes after his assailant departed the scenedid not require resolution of the issue. ${ }^{252}$ Among other cases, the court cited Freed.

Certainly Freed emboldened the Parker prosecutor to argue as he did, and Freed did nothing to discourage the appellate court from ruling as it did. If Freed had instead forcefully asserted the need to prove a culpable mental state in every prosecution for a serious crime, both the argument and the ruling in Parker might well have been different.

The mens rea holding in Freed spawned a number of dubious decisions and an even larger number of dubious prosecutions. ${ }^{253}$ These injustices are part of the price to be paid for failing to construe strictly criminal statutes.

\section{United States $v$. Bass: Promise in the Holding but Danger in the Dicta}

In contrast to the costs imposed by United States $v$. Biswell and United States v. Freed are the benefits flowing from United States $v$. Bass. Of course, the benefits of strict construction are almost always invisible. No reporter system details exercises of discretion not to arrest and not to prosecute. Thus, it is impossible to document all that the strict construction in Bass achieved. One can only recount those reported decisions that have applied the reasoning of Bass to other areas of criminal law and to other aspects of the Gun Control Act of 1968 .

The Supreme Court has used Bass to disapprove consecutive sentences for felony murder and the underlying felony, ${ }^{254}$ and to allow a criminal defendant to challenge the propriety of the antipollution regulation under which it was prosecuted. ${ }^{255}$ Most of the courts of appeals also have relied on Bass in

250. Id. at 1306.

251. Id.

252. Id. ("That possession is momentary is immaterial."): see United States v. Hammonds, 566 F.2d 1301 (5th Cir. 1977) (companion case resolved in similar fashion). But of. People v. King. 22 Cal. 3d 12, 582 P.2d 1000, 148 Cal. Rptr. 409 (1978) (contrary interpretation of similar state statute); State v. Hardy, 60 Ohio App. 2d 325, 397 N.E.2d 773 (1978) (same).

253. Even Freed's sub silentio holding regarding the mens rea requirement for conspiracy, see supra text accompanying notes 126-27, has borne fruit. See United States v. Feola, 420 U.S. 67I (1975) (citing Freed) (mens rea for conspiracy to assault federal officer same as for substantive offense); United States v. Schwartz, 464 F.2d 499 (2d Cir. 1972) (citing Freed) (mens rea for conspiracy to violate antihypothecation statute same as for substantive offense); see also United Statcs v. Burkhalter, 583 F.2d 389 (8th Cir. 1978) (mens rea for aiding and abetting violation of 26 U.S.C. $\$ 5861$ (1982) same as for substantive offense); United States $\therefore$. Bell, 573 F.2d 1040 (81h (.ir. 1978) (same holding with regard to Burkhalter's codefendant). Affirming convictions in reliance on a resolution by default must surely weaken confidence in the judicial process.

254. Whalen v. United States, 445 U.S. 684 (1980).

255. Adamo Wrecking Co. v. United States, 434 U.S. 275 (1978). But sef Mckilroy $:$ Linited States, 455 U.S. 642 (1982) (rejecting rule of lenity as applied to statutc prohibiting interstatc 
strictly construing penal statutes. There are decisions to this effect in the First, ${ }^{256}$ Second, ${ }^{257}$ Fifth, ${ }^{258}$ Sixth, ${ }^{259}$ Seventh, ${ }^{260}$ Ninth, and Tenth Circuits. ${ }^{261}$

Most prolific in its reliance on Bass has been the Ninth Circuit. There, fidelity to the rule of lenity has produced decisions holding that purchasing drugs for personal use is not facilitation of a drug-trafficking conspiracy, ${ }^{262}$ that Forest Service employees are not protected within the terms of the statute prohibiting assaults on federal officers, ${ }^{263}$ that remote sellers of gambling devices do not facilitate the gambling done with those devices, ${ }^{264}$ that entry into the United States is complete only when one is free from official restraint, ${ }^{265}$ that forged postal money orders fall within an exclusion from the National Stolen Property Act, ${ }^{266}$ and that violations of administrative regulations punishable only by civil sanctions do not render a gambling operation illegal. ${ }^{267}$

The variety of these cases suggests the far-reaching effect that one instance of strict construction can have on lower courts. But this is just the tip of the iceberg: Apart from the judiciary are the prosecutors, whose attitudes toward marginal prosecutions are reoriented by an example of strict construction.

transport of forged securities). Regarding the Bass dictum on maintaining federal-state balance, compare United States v. Enmons, 410 U.S. 396 (1973) (Hobbs Act, 18 U.S.C. \& 1951(a) (1982), does not apply to violence during legal strike), with Perrin v. United States, 444 U.S. 37 (1979) (commercial bribery is unlawful activity under Travel Act, 18 U.S.C. \& 1952 (1982)), and United States v. Culbert, 435 U.S. 371 (1978) (racketeering is not element of offense and thus not necessary to convict under Hobbs Act, 18 U.S.C. $\$ 1951$ (a) (1982)).

256. United States v. Rossi, 552 F.2d 381 (Ist Cir. 1977) (rejecting consecutive sentences under federal bank robbery statute, which punishes both bank robbery and killing while robbing bank).

257. United States v. Mennuti, 639 F.2d 107 (2d Cir. 1981) (private residence not property used in commerce or in activity affecting commerce under federal arson statute); United States v. Dixon, 536 F.2d 1388 (2d Cir. 1976) (mailing false proxy solicitation does not constitute mail fraud). In Dixon, Judge Friendly remarked: "We begin by expressing some wonder why the prosecutor thought it necessary or desirable to include the mail fraud counts." Id. at 1398.

258. United States v. RSR Corp., 664 F.2d 1249 (5th Cir. 1982) (private carrier not subject to federal statute criminalizing willful falsification of motor carrier records); United States v. Grissom, 645 F.2d 461 (5th Cir. 1981) (intent to defraud government necessary element of fraudulently disposing of property mortgaged to government); United States v. Slater, 524 F.2d 987 (5th Cir. 1975) (knowledge of duty to report for induction necessary element of failure to report for induction).

259. United States v. Jenkins, 554 F.2d 783 (6th Cir. 1977) (causing government to expend funds in eviction proceeding does not constitute depredation of federal property).

260. United States v. Anton, 683 F.2d 1011 (7th Cir. 1982) (statute prohibiting reentry into United States by deported alien requires mens rea; see supra text accompanying note 218); United States v. Capen, 57 l F.2d 374 ( 7 th Cir. 1978) (failure to appear before federal marshal, as condition of bail, does not constitute failure to appear before judicial officer); United States v. Isaacs, 493 F.2d 1124 (7th Cir. 1974) (the act of transporting checks across state line after negotiation does not constitute use of facility in interstate commerce under Travel Act, 18 U.S.C. $\$ 1952$ (1982)).

261. United States v. O'Brien, 686 F.2d 850 (10th Cir. 1982) (statute prohibiting unlawful acquisition of food stamps requires mens rea).

262. United States v. Martin, 599 F.2d 880 (9th Cir. 1979).

263. United States v. Patrin, 575 F.2d 708 (9th Cir. 1978).

264. United States v. Gibson Specialty Co., 507 F.2d 446 (9th Cir. 1974)

265. United States v. Oscar, 496 F.2d 492 (9th Cir. 1974).

266. United States v. Garlardi, 476 F.2d 1072 (9th Cir. 1973) (interpreting 18 U.S.C. $\$ 2314$ (1982)).

267. United States v. Gordon, 464 F.2d 357 (9th Cir. 1972). 
And when these shifts in attitude are communicated to agents and investigators, their perspectives change as well.

Regarding the Gun Control Act of 1968, the Bass decision's adherence to strict construction had an impact on parts of the Act other than the specific provision at issue in that case. In Simpson $v$. United States ${ }^{268}$ and Busic $v$. United States, ${ }^{269}$ the Supreme Court disapproved prison sentences under section 924 of title 18, which imposes an additional sentence on anyone who commits a federal crime with a firearm, ${ }^{270}$ when the underlying federal crime also contains a provision enhancing the sentence because of the use of a firearm. Both decisions relied on Bass. ${ }^{271}$

The courts of appeals have used Bass to condemn a number of dubious prosecutorial tactics. In United States $v$. Schultheis, ${ }^{272}$ for example, the government claimed that Schultheis was a convicted felon in possession of a firearm, in violation of section 1202 of the appendix to title 18. This provision defines a felony as "any offense punishable by imprisonment for a term exceeding one year, but . . . not includ[ing] any offense (other than one involving a firearm or explosive) classified as a misdemeanor . . . and punishable by a term of imprisonment of two years or less." 273 Schultheis' "felony" was simple assault, a common law misdemeanor in Maryland with no statutorily stated maximum sentence. ${ }^{274}$ A Maryland court had given Schulteis a ninety-day suspended sentence, a twenty-five dollar fine, and two years' unsupervised probation. ${ }^{275}$ The district court convicted Schultheis of violating section 1202, classifying his assault as a felony. The Fourth Circuit reversed, finding "a latent ambiguity" in the definition of felony ${ }^{276}$ and quoting Bass for the proposition that such ambiguities should be resolved in the defendant's favor. ${ }^{277}$

Another prosecution that should never have commenced was United States v. Dalpiaz, ${ }^{278}$ in which the government charged a violation of section 5861 of the Internal Revenue Code resulting from Dalpiaz's alleged possession of an

\footnotetext{
268. 435 U.S. 6 (1978).

269. 446 U.S. 398 (1979).

270. See supra text accompanying note 79 .

271. But see United States v. Batchelder, 442 U.S. 114 (1979) (rule of lenity does not require sentence under 18 U.S.C. app. $\$ 1202$ (1982) (two-year maximum), instead of under 18 U.S.C. $\$ 922$ (1982) (five-year maximum), even though identical conduct violates both provisions); see also Dickerson v. New Banner Inst., 460 U.S. 103 (1983) (expunged felony conviction satisfies felon! requirement under $1968 \mathrm{Act}$ ); Lewis v. United States, 445 U.S. 55 (1980) (felony conviction defective under Gideon v. Wainwright, 372 U.S. 335 (1963), satisfies felony requirement under 1968 Act): Scarborough v. United States. 431 U.S. 563 (1977) (see infra text accompanying notes 304-05); Barrett v. United States, 423 U.S. 212 (1976) (see infra note 297); Huddleston v. United States. 415 U.S. 814 (1974) (pawnor's redemption is acquisition under 18 U.S.C. $\$ 922($ a)(6) (1982)).
}

272. 486 F.2d 1331 (4th Cir. 1973).

273. 18 U.S.C. app. $\$ 1202$ (c)(2) (1982); see supra note 80.

274. Schultheis, 486 F.2d at 1332.

275. Id.

276. Id. at 1335 .

277. Id. at 1334-35 (quoting Bass. 404 U.S. at 347-48).

278. 527 F.2d 548 (6th Cir. 1975). 
unregistered "destructive device." 279 The device in question was a "ground burst projectile simulator . . . used by the military in the training of infantry troops. It simulates incoming artillery fire and exposes the troops to the accompanying sound effects."'280 The prosecution contended that the simulator was a destructive device because it was a "missile having an explosive or incendiary charge of more than one-quarter ounce." 281 Willing to accept this contention, the Sixth Circuit nevertheless reversed Dalpiaz's conviction because of a statutory exemption for devices "neither designed nor redesigned for use as a weapon." 282 The court construed this language as a reference to the designs of the device's maker, ${ }^{283}$ and not to those of its possessor, ${ }^{284}$ citing Bass in support of this strict construction. ${ }^{285}$

In the courts of appeals, the emphasis in Bass on the lenity principle has most affected the determination of the number of charges for simultaneous acts. In United States $v$. Kinsley, ${ }^{286}$ the Eighth Circuit Court of Appeals reversed the multiple convictions of former felons who had been found in possession of four firearms "at a single time and place." 287 Their trial resulted in four convictions under section 1202 of the appendix to title 18 and four sentences (three consecutive and one concurrent) for each defendant. ${ }^{288}$ After extended consideration of the rule of lenity and the language, history, and structure of section 1202, the appellate court found that simultaneous possession of multiple weapons was but one offense. ${ }^{289}$ Similarly, in United

279. See supra text accompanying note 85 .

280. Dalpiaz, 527 F.2d at 549. Specifically,

the simulator could be described as a hand-thrown missile . . . that . . . contains approximately two ounces of photo-flash material. ... [T]he device does not project any type of metal upon detonation but expels only the cardboard of which it is composed. However, . . . if the device detonates while lying on the ground, it makes a shallow depression in the ground and hurls out, at a rather high velocity, any gravel or sticks near it. . . . [I]f the device should detonate while being held, the force would probably take off most of a person's hand.

Id. at $\mathbf{5 5 0}$.

281. 26 U.S.C. $\& 5845(f)(1)(D)$ (1982); see supra note 280.

282. Id. §5845(f); see 527 F.2d at 551 .

283. Dalpiaz, 527 F.2d at 551.

284. Dalpiaz had attempted to carry the simulator aboard an airplane, thus giving credence to the argument that he planned to use the device as a weapon. $527 \mathrm{~F} .2 \mathrm{~d}$ at 549 . But see id. at 551 ("the record does not reveal what Dalpiaz intended to do with the simulator"). In a separate trial, Dalpiaz had been convicted of violating 49 U.S.C. \$ 1472(1) (1982) (attempting to board aircraft while carrying concealed deadly weapon); the simulator was the concealed "deadly weapon." After this trial, the government charged him with violating 26 U.S.C. $\$ 5861$ (1982). See Dalpiaz, 527 F.2d at 549.

285. 527 F.2d at 552; $c$. United States v. Posnjak, 457 F.2d 1110 (2d Cir. 1972) (intent to use sticks of dynamite as weapon does not render them destructive devices).

286. 518 F.2d 665 (8th Cir. 1975).

287. Id. at 666 .

288. Id.

289. Id. at 666-70; accord United States v. Marino, 682 F.2d 449 (3d Cir. 1982); United States v. Powers, 572 F.2d 146 (8th Cir. 1978); United States v. Rosenbarger, 536 F.2d 715 (6th Cir. 1976). Bul of. United States v. Oliver, 683 F.2d 224 (7th Cir. 1982) (when received at different times. multiple weapons will support multiple possession counts): United States $v$. Wiga, 662 F.2d 1325 (9th Cir. 1981) (same); United States v. Bullock, 615 F.2d 1082 (5th Cir. 1980) (same); United States v. Killebrew, 560 F.2d 729 (6th Cir. 1977) (same). 
States $v$. Burton, ${ }^{290}$ the Fourth Circuit disapproved consecutive sentences for a convicted felon's receipt of a weapon under section 922 of title 18 and for his possession of the same weapon under section 1202 of the appendix to that title. $^{291}$ The court relied on the rule of lenity, citing Bass. ${ }^{292}$

These cases are the most discernable fruits of the Bass decision's strict construction, ${ }^{293}$ but certainly are not the only ones. For each of these reported instances of restraint, there surely were many that went unnoticed, but which nevertheless reduced the incidence of overzealous law enforcement.

Ironically, the rule of lenity has had the least impact on the precise concern of the Bass opinion, the commerce nexus in possession cases under section 1202 of the appendix to title $18 .^{294}$ On this point, the ill-considered dictum in Bass regarding receipt prosecutions has had a greater effect than the rule of lenity.

The Bass Court rendered two unnecessary opinions. ${ }^{295}$ The less egregious of the two was advice on how to prove possession in commerce (which was the precise issue in Bass): "[A] person 'possesses . . . in commerce or affecting commerce' if at the time of the offense the gun was moving interstate or on an interstate facility, or if the possession affects commerce."'296 Far more gratuitous were the Court's suggestions regarding proof of receipt in commerce: "[T]he Government meets its burden here if it demonstrates that the firearm received has previously traveled in interstate commerce.",297

290. 629 F.2d 975 (4th Cir. 1980).

291. Accord United States v. Wiga, 662 F.2d 1325 (9th Cir. 1981); United States v. Girst, 645 F.2d 1014 (D.C. Cir. 1979), vacating 636 F.2d 316 (D.C. Cir. 1979); see also United States v. Clements, 471 F.2d 1253 (9th Cir. 1972) (disapproving consecutive sentences under 26 U.S.C. $\$ 5861$ (c)-(d), (f) (1982); see supra text accompanying notes 88-89); cf. United States v. Batchelder, 442 U.S. 114 (1979) (in possession case, prosecutor may proceed either under $\S 922$ or under $\S 1202$ ).

292. Burton, 629 F.2d at 977-78.

293. See also United States v. Plyman, 551 F.2d 965 (5th Cir. 1977) (citing Bass on proper federalstate balance in law enforcement, court disapproved prosecution of dealer for intrastate sale of firearm, even though dealer thought buyer was from out of state); United States v. Kraase, 484 F.2d 549 (7th Cir. 1973) (same).

294. 18 U.S.C. app. \$1202(a) (1982); see supra text accompanying note 80.

295. See supra text accompanying notes $154-58$

296. 404 U.S. at 350 .

297. Id. In a footnote, the Court added, "This reading preserves a significant difference between the 'receipt' offenses under" $\$ \S 1202$ and 922 , both of which prohibit a convicted felon's receipt of a firearm, id. at $350 \mathrm{n} .18$; the latter provision, the Bass Court noted elsewhere in its opinion, "is limited to the . . receiving of firearms as part of an interstate transportation." Id. at 342-43 (citing Tot v. United States, 319 U.S. 463 (1943), which interpreted the predecessor statute to 18 U.S.C. $\$ 922(h)$ (1982)). Thus, according to the Bass Court, receipt under $\S 922$ was limited in the same way as possession under $\S 1202$.

This understanding of $\S 922$ lasted only until the Court's decision in Barrett v. United States, 423 U.S. 212 (1976), which determined that $\$ 922$ reached all receipts by convicted felons of firearms that had been in interstate commerce at any previous time. The Barell Court spurned the reading of $\$ 922$ found in $T o t$ and Bass and relied instead on the Bass dictum regarding receipt in commerce under $\S 1202$ :

To hold, as the Court did in Bass, that [section 1202] . . requires only a showing that the firearm received previously traveled in interstate commerce, but that [section 922] . . . is limited to the receipt of the firearm as part of an interstate movement, would be inconsistent construction of sections of the same $\mathrm{Act}$.... 
Thus, under Bass, possession in commerce demanded a showing of contemporaneous interstate travel, while receipt in commerce required interstate travel only at some previous time.

The courts of appeals were quick to accept the Bass Court's permissive suggestion regarding proof of receipt in commerce, ${ }^{298}$ but some bridled at the relatively strict construction concerning possession in commerce. Most recalcitrant was the Sixth Circuit, which commented in a 1972 opinion: "While, as the Supreme Court pointed out, the offense of receiving may have a broader aspect than the offense of possessing, . . . [w]e have difficulty . . . in comprehending how it is possible for a person to possess something that he did not receive." 299

Still motivated by the same spirit, the Sixth Circuit in 1976 disavowed the restrictive Bass dictum regarding possession in commerce, choosing instead to apply the view of the commerce nexus in receipt prosecutions set out in Bassthat previous interstate movement, by anyone at any time, was sufficient-to all prosecutions under section 1202, whether for possession or for receipt. In United States $v$. Jones, ${ }^{300}$ the court announced: "[T] he course of conduct which Congress intended to punish is the same regardless of whether the facts . . . show a receipt or a possession. There is no logic in the position that a nexus sufficient to support a conviction for receipt . . . will not also support a conviction for possession ...."301 The Sixth Circuit thus flatly refused to follow the Supreme Court's explicit strict construction in Bass. ${ }^{302}$

Some other circuits were not as bold and applied the Court's strict construction, ${ }^{303}$ but their timidity later proved to be misguided. When the matter of the commerce nexus in possession cases again reached the Supreme Court in Scarborough v. United States, ${ }^{304}$ the Court found it easy to abandon one Bass dictum in favor of the other, more permissive dictum. In the course of holding that a convicted felon violates section 1202 by possessing a firearm that has previously been in interstate commerce, the Court brushed off its previous, more limited interpretation of possession in commerce: "While

423 U.S. at 224 (citations omitted). Thus, the Bass dictum regarding receipt in commerce under $\S 1202$ paved the way for diluting the commerce nexus required under $\S 922$.

298. E.g., United States v. Haddad, 558 F.2d 968 (9th Cir. 1977). With regard to receipt in commerce under $\$ 922$, see supra note 297.

299. United States v. McCreary, 455 F.2d 647, 650 (6th Cir. 1972) (Weick, J.).

300. 533 F.2d 1387 (6th Cir. 1976) (Weick, J.).

301. Id. at 1392-93. In support of this contention, the court in Jones cited Barrett v. United States, 423 U.S. 212 (1976), aff g 504 F.2d 629 (6th Cir. 1974) (Weick, J.) (see supra note 297), which had used the Bass dictum regarding receipt in commerce under $\$ 1202$ to weaken the receipt-incommerce requirement of $\S 922$. Jones, $533 \mathrm{~F} .2 \mathrm{~d}$ at 1393 n.3.

302. Accord United States v. Scarborough, 539 F.2d 331 (4th Cir. 1976), affd, 431 U.S. 563 (1977); United States v. Burns, 529 F.2d 114 (9th Cir. 1975); United States v. Bumphus, 508 F.2d 1405 (10th Cir. 1975).

303. See United States v. Malone, 538 F.2d 250 (9th Cir. 1976); United States v. Ressler, 536 F.2d 208 (7th Cir. 1976); United States v. Bell, 524 F.2d 202 (2d Cir. 1975); United States v. Pleasant. 469 F.2d 1121 (8th Cir. 1972), on appeal after remand, 489 F.2d 1028 (8th Cir. 1974).

304. 431 U.S. 563 (1977). 
such a requirement would make sense, further consideration has persuaded us that that was not the choice Congress made."305

In this fashion, the wholly unnecessary dictum in Bass regarding receipt in commerce became the lowest common denominator of section 1202 , forcing the commerce nexus for other aspects of the section down to its level. ${ }^{306}$ As with Freed's enthusiastic adoption of strict liability, the Bass Court's departure from the rule of lenity had repercussions both unforeseen and unfortunate. ${ }^{307}$

\section{$\mathrm{V}$ \\ Conclusion}

Before studying firearms offenses, my attitude toward gun control was a positive one. Without much reflection, I believed that gun control would reduce crime and violence with only minor inconvenience to the ordinary citizen.

Analysis of the implementation of the Gun Control Act of 1968 has reformed this attitude. Unless carefully monitored by the courts, new gun control legislation will lead to overzealous law enforcement, which will take a very high toll on the ordinary citizen. ${ }^{308}$ This article has attempted to demonstrate that with regard to the most significant existing gun control statute, our highest court has not discharged its duty of careful monitoring. There is little reason to believe that other courts have performed better. Thus, enthusiasm for gun control must be suspended, at least until this judicial record improves.

There is a wider message in this shift in my opinion. Without a judiciary committed to strict construction, the public could eventually grow suspicious of any proposed change in the law of crimes. Without a mechanism for discouraging police and prosecutors from extending the scope of new language in the criminal statutes, the populace (through the legislature) might choose instead to cling to present laws, whatever their deficiencies. Widespread adoption of this attitude would paralyze needed criminal law reform.

Perhaps this thinking is precisely what underlies the public's suspicion of gun control. Liberal readings of current statutes have led to abusive investigations and dubious prosecutions. The reaction of many gun owners has been to distrust the motives of those who propose even the mildest forms of gun control, ${ }^{309}$ producing a political stalemate.

Strict construction of existing weapons statutes will ultimately diminish this distrust. To facilitate a measured process of reform in this and in other areas of criminal law, as well as to restrict arbitrary and discriminatory law

305. Id. at $575 \mathrm{n} .11$ (citations omitted).

306. The Bass dictum had the same effect on the commerce nexus under $\$ 922$. Sep supra note 297.

307. See supra text accompanying notes 206-53.

308. See supra text accompanying note 21 .

309. See supra text accompanying notes 7-9. 
enforcement, all courts should adhere to the fundamental notion that criminal statutes should be strictly construed in the defendant's favor. 